University of Louisville

ThinkIR: The University of Louisville's Institutional Repository

Electronic Theses and Dissertations

1936

\title{
Vapor-liquid equilibrium data and other physical properties of the ternary system ethanol, glycerine, and water
}

Charles H. Watkins 1913-2004

University of Louisville

Follow this and additional works at: https://ir.library.louisville.edu/etd

Part of the Chemical Engineering Commons

\section{Recommended Citation}

Watkins, Charles H. 1913-2004, "Vapor-liquid equilibrium data and other physical properties of the ternary system ethanol, glycerine, and water" (1936). Electronic Theses and Dissertations. Paper 1940.

https://doi.org/10.18297/etd/1940

This Master's Thesis is brought to you for free and open access by ThinkIR: The University of Louisville's Institutional Repository. It has been accepted for inclusion in Electronic Theses and Dissertations by an authorized administrator of ThinkIR: The University of Louisville's Institutional Repository. This title appears here courtesy of the author, who has retained all other copyrights. For more information, please contact thinkir@louisville.edu. 


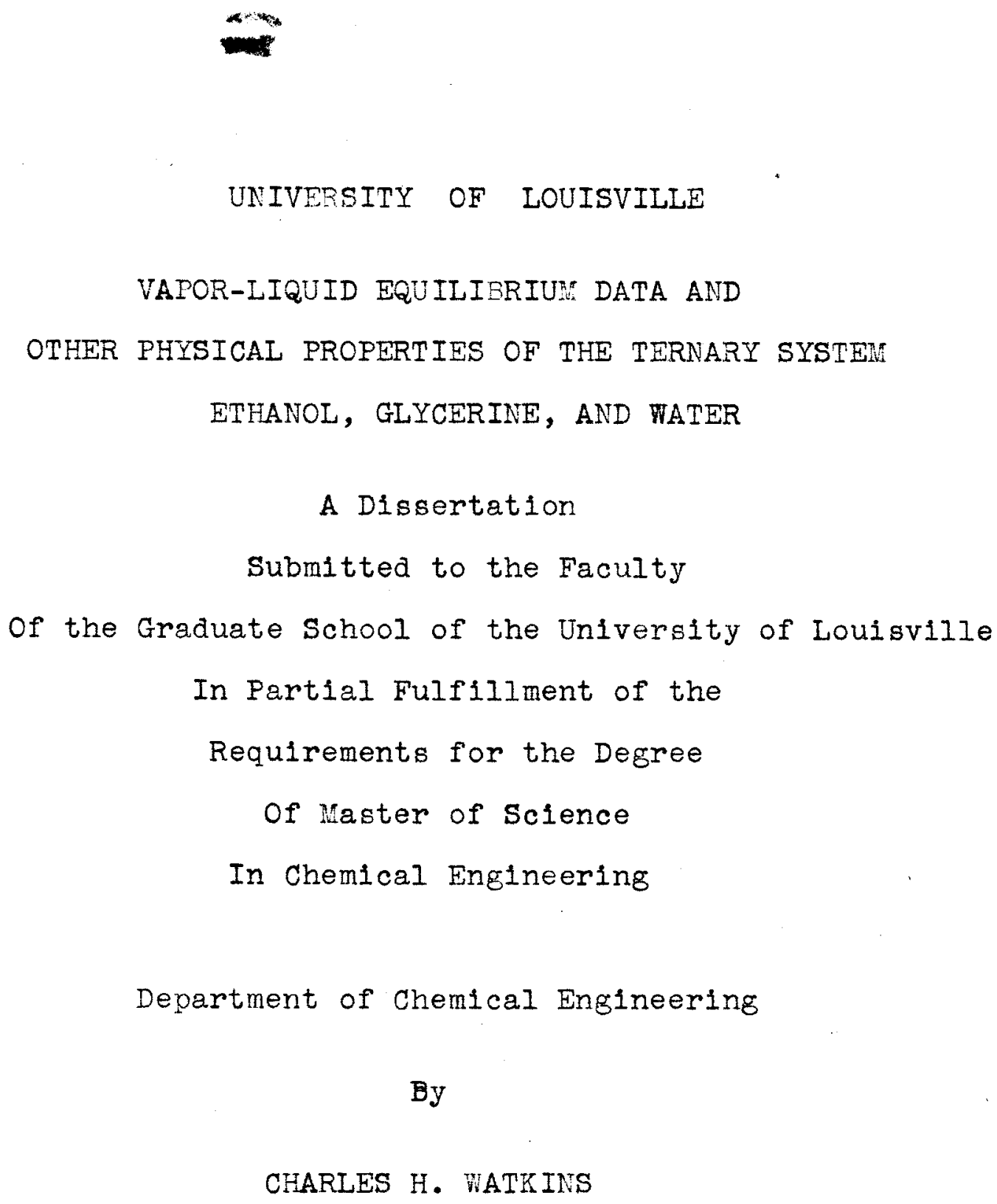


TABLE OF CONTENTS

chapter Page

I Introduct1on-

II Theoret1c8I- 1 con

II Apparatue \& Frocedure--- ---12

IV Experimental

Hater1alg

Preparation of Samplee-- $\ldots--22$

Spec1f1c Heato-n-

Do111ng: PolntB-n-

Vapor Pregsure--

Latent Heata-n-

Vapor-L1quid Equ111br1um--m---53

Freezine polnt:-

V Conclusions-

VI F1b110graphy-n- 
LIST OF TABLES

Table

Fage

I Physical Propertios of Furlfied

Nater1als-......

II Composition of Samples--..-.-.-24

II Specific Heats, Boling Points

and Latent Heat

IV Vapor Pressure Data-_-_.

V Vapor-L1qu1d Equ111brium Data---56

VI Vapor-L1quid Composition Data

for Ethanol-

VII Freezing rolnt 


\section{LIST OF ILLUSTRATIONS}

F1g. I Vapor Pressure of Pure kater1als--9

F1g. 2 Spec1f10 Heat Apparatue-......-.-14

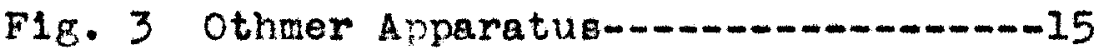

F1g. 4 Ternary Dlagram of refractive index and denelty-......................

F1g. 5 Bolling polnt Apparatus-n...-.-13

F1g. 6 spec1fio Heat Bino1del Curve-n----32

F1g. 7 Specif1c Heat Trlangular Dlagram--33

F1g. 3 Bolling Polnt B1noldal Curve-----35

Fig. 9 Bolilnk rolnt Ternary Diagram-.---36

F1g. 10 vapor Pregeure Curvee-n.......-43

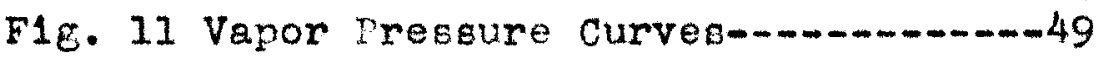

FIG. 12 vapor Presrure curves-...-...-50

F1g. 13 Vapor-L1quid Equ1l1brium Compo-

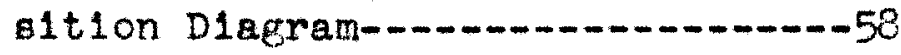

F1g. 14 Liquid ve vapor composition curves for ethanol-an

F1g. 15 Freozing polnt Pinoldal curve-.---65 F1. 16 Freozine Folnt Ternary Diagram----66 
ACKNONLEDGEMENT

The athor wiehes to express his apprecintion for the helpful sugeetions rendered by Dr. Robert $\sigma$. Ernat, who directed this reserech. 
GHAPTER I

INTRODUCTION 


\section{INTRODUCTION}

The purpose of this investigation $1 \mathrm{~s}$ to obtain vapor-11quid equlibrium dats and to determine specific heats, boling polnts, latent heats, and vapor pressures for the ternary aystem-ethanol, glycerine, and water. In a previous investigation (1) densities, viscosities, eurface tensions, and refractive indicles were reported. The Data of these tro inveetigetions are to be uged in the study of alstillation of thie ternary mixture in a sem1-comercial eleht plate fractionatine column.

Nelman (2) invest1gated the oystem, butanol, acetone, and water for vapor-11quid equilibrium data and c noluded that these pure meterlale can be separnted by: 1 . d10t1ling in a fracti ning column elving almost pure acetone, 2. ceparatine the butanol from the moter because of their 1mmisolbility and, 3. purlf1cetion of the materlals by further frectionation. It is honed that gone slmilar correlation can be made for the sycter--ethanol, glycerine and vater.

Brungee and Furnas (8) prepared vapor-11qu1d equ111brium diacrame of two binary mixturee of comercially important orenic colvent:. n-butmol-n-batyl acetate and n-butnnol-acetone. The othmer apparatus wan used in obtainine the datr, and it ws found that $n-b u t$ nol-n-butyl 
acetate formed an azeotropic mixture at 72.9 mole $\%$ alcohol, holling at $115.5^{\circ} \mathrm{C}$, at $760 \mathrm{~mm}$. Mercury; however, the system $n$-butanol-acetone formed no azeotroplc mixture. Ernot, L1tkenhous, and Ppanyer deternined the bollIng pointe, and other phyelcal properties, of the systemn-butanol, acetone and water using a modification of the Cottrel Apparatue (10). All bolling polnts were found to be intermediate between those of the pure subrtances. The determinetion of vapor-liquid equilibrium data, epecific heats, latent heate, bolling polnts, and vapor presouree wag undertaken in this invertigation and these properties are reported herein, both rraphically and in table form. 
CHAPTER II

THEORET IGAL 
THEORETICAL

The deternination of the physloal properties undertaken in this investiga:ion include those necessary and directly used in the etudy of distillation on a comerclal scale. These properties are all heat functions. In comerclal als t1ilation, the 11quid feed to be distilled 1s usually in ctorage at roon temperature. on leaving atorage the foed is pased through proheaters where 1 ts tenterature 15 ralsed to the bolling point. Imediately after entering the still at its bolling point, the feed is vaporizes ond the vapors are continuously condensed and vaporlzed on each plate in the column. The vapors from the top plate are condenged and caught in the recelver.

When the feed is passed through the preheater, heat 1a added to 1t, which raloes the temperature and increares the vapor preosure. When the vapor pres ure 10 ralsed to the pressure of the surroundinge, the bolline polnt of the 11quid 1 reached. At this temporature latent heat nust be added to vaporize the 11quid. When the llquid 1s vaporized, Its compoltion can be obtained from vapor-Ilquid compostion data. In this wy, the propertios determined are appIled to the study of distillation. For instance, latent hed and bpecific heats are used in calculating the steam concumption. Bolling polnts ind lcate the steam temperature 
and preasure to be used. From the vapor-11qu1d equil1brium data, can be calculated the recult at any stale of dist1lIation.

Accordine to the kinetic theory there is a continuous flight of partioles of vapor from the surface of a Ilquid Into the free epace above 1t. S1multanoous to this emmiseIon of vapor particles, there $1 \mathrm{~s}$ a reverse process of condensation at the surface of the 11quid. If thls system of vapor and Ilquid is in a closed venel, there vill exist a definite equ1librium betwen the liquid and 1te vapor when the rate of emingion is exactly equal to the rate of condensation. The prescure exerted by the vapor in equilibrium Fith the 11quid phase at a certain temperature 10 the varor prossure of the 11quid at that temerature. This equilibrium is dependent unon the temperature. For every temperature, then, there $1 \mathrm{~s}$ a definte equ1librium pressure, and conversely, for every pressure there existe a definlte temperature at which vapor and 11quid are in equllibrium with each other. The temperature correspondine to the equilibrium pressure of $760 \mathrm{~mm}$. of mercury is the bolling point of the 11quid. The vapor pressure of a 11quid in a constant at a definite temperature, and is entirely inderendent of the amounte or 11 quid and vepor frerent: hovever, it increaree as the temperature 18 increared. F1g. I showo the vapor 
preasure of ethanol, glycerine, and wer at varlous temperatures.

To Increase the temperature of a 11quid, energy is supplied in the form of heat and is called speo1fic heat. Srecific heat may be defined as the amount of heat necessary to ralse a unit quantity of substance a unit change in temperature, or to be specific, it may be defined as the number of calorles necesary to raise one gram of the liquid one degree cent1rrade. In order to transform a l1quld into a vapor, enercy 10 required to overcome intermolecular attraction of the molecules and also to increare the volume of the fluld agalnet atmoopherlc pressure. Thio energy is supplied in the form of heat and 18 called latent heat of vorization and may be defined as the number of calories of heat necensary to convert one gram of a Ilquid at 1ta bolling point into vapor at the same tenperature. The liquid referred to in this diecussion may be a single subatance or a mixture of tro, three, or four liquide.

A ueeful relation betwen vapor pressure, tenperature, and hent of vorization war developed by Clapeyron ( $z$ ). It may be develoned in an approximate menner with the hel: of a eingle thernodynamical cycle elmilar to Carnot's. 


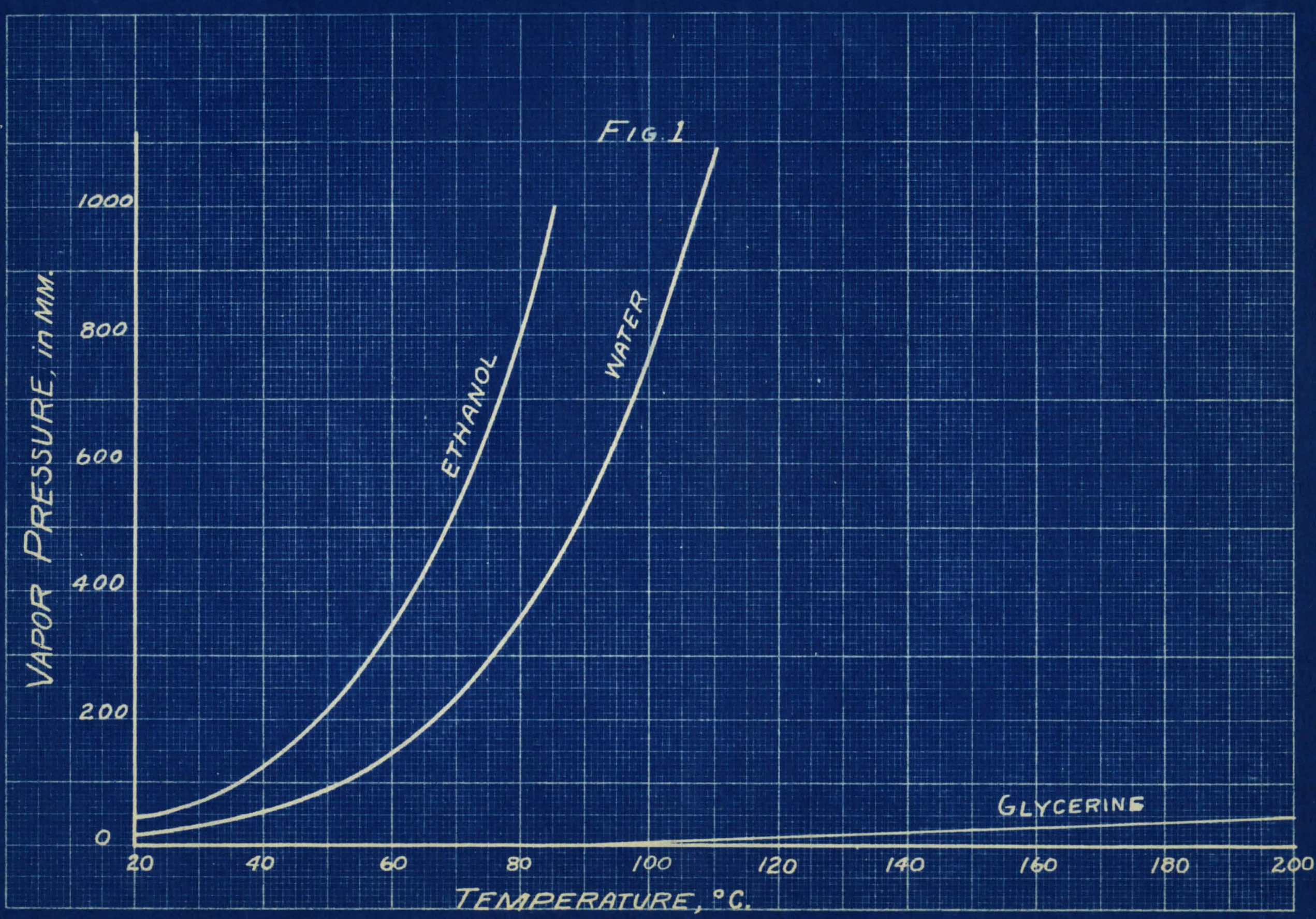


Anluine carnot's cyclo and the rocond $12 \%$ of thernodymates, the differentiol fort of the equation may be prittion:

$$
\frac{d v}{d T}=\frac{I_{1}}{T\left(V_{2}-V_{1}\right)}
$$

mich is mom ar the claneyron ecuation.

where I. Intent heat of varorizstion.

T - Bholute tementure.

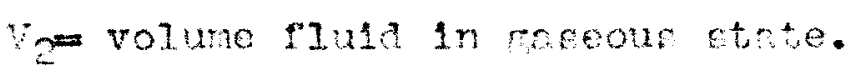

$y_{1}-$ rolume of $12 \mathrm{guld}$

$$
\begin{aligned}
\frac{d p}{d T} & \text { aorivative of the pocoure with } \\
& \text { recrect to the temenature. }
\end{aligned}
$$

Clauchu moned how the laneyron oquation

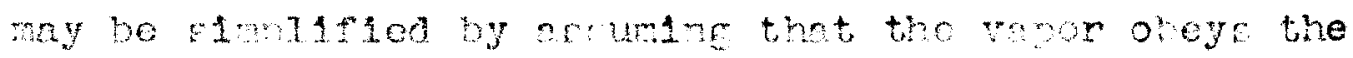

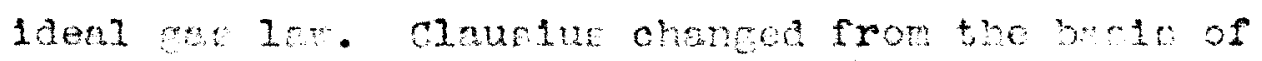

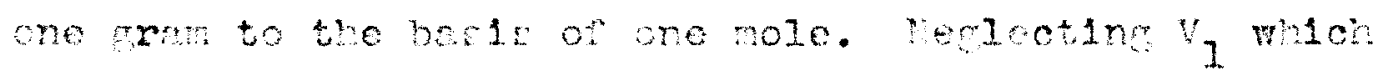

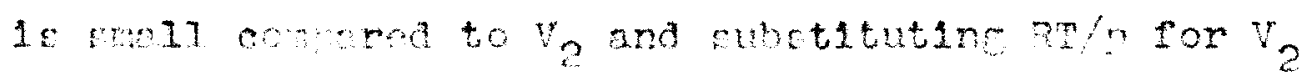

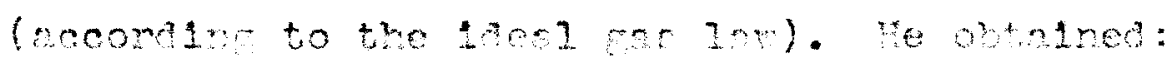

$$
\begin{aligned}
& \frac{d}{\partial t}=\frac{1}{2}
\end{aligned}
$$

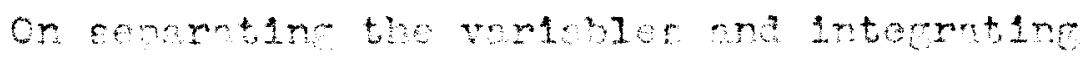

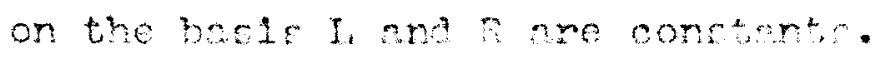

$$
1000=\frac{-1}{N T}+c
$$


where $C$ is the constant of integration. This equation 1s Ilnear in $\log _{\theta} P$ and $I / T$, and when these quantities are plotted a etralght line results, the elope of which 18 $-L / R$. Using this fact the vapor presures determined in thif invertigation are shown graphlcally In Figures 10, 11 , and 12 with $\log p$ plot ed agalnst $1 / T$. If equation (2) is integrated between the I1mits of $\mathrm{P}_{2}, \mathrm{P}_{1}$ and $\mathrm{T}_{2}, \mathrm{~T}_{1}$, the following equation resulte:

$$
\log _{e} \frac{F 2}{P 1}=\frac{-L}{R} \div\left(\frac{1}{T_{2}}-\frac{1}{T_{1}}\right]
$$

Where $\mathrm{P}_{2}$ is the vapor pressure at $\mathrm{T}_{2}$ and $\mathrm{P}_{2}$ is the vanor precoure at $T_{1}$. colving eqution (4) for $L$,

$$
\text { I. }-2.303 R \log _{10} \frac{F_{2}}{P_{1}} \div\left[\frac{1}{T_{1}}-\frac{1}{T_{2}}\right]
$$

Where $\mathrm{L}$ is the latent heat 1 in calorien per mole. rquation (5) 1s used in this invertigntion for cal culating latent heate as describca in chapter IV. 
CHAPTER III

APPARATUS and PROCDDURE 


\section{APRERATUS AND PROCEDUNE}

Speciflc heats (6) were determined by introducing a measured quantity of electricity into the cample and recording the tempe ature rise. A portable watt second meter and a thermometer with one-tenth deEree raduations vere used to determine these valuea. A carbon resietor was ued as a heating element. Thie apharatus inclosed in a sliver plated glas tube surrounded by an evacuated jacket, a ske oh of which is ohown in F1g. 2 .

VATOR LIQUID EQUILIBRIUn. A modification of the Othmer Apporatus (7) was used to obtain the vapor11 cuid equilibrium data. The apparatus (Fig. 3) conilete of a still, a condeneer, a recelver, and an overflow or $r$ flux connection. The sample is placed in the st1ll body from which it is vaporlzed. The condenced vapors fall from the condeneer into the recelver. When the latter 1 fllled, the liquid is refluxed to the et1il body and the cycle is repeated. As the l1suld falls from the condencer, it is fed to the bottom of the recelvem: this operation ineures thorough mixing and equilibrium conditione. The temerature rlees at the beginning of the run intil the recelver is filled. Ater refluxing begins, 11t:le change in temperature 


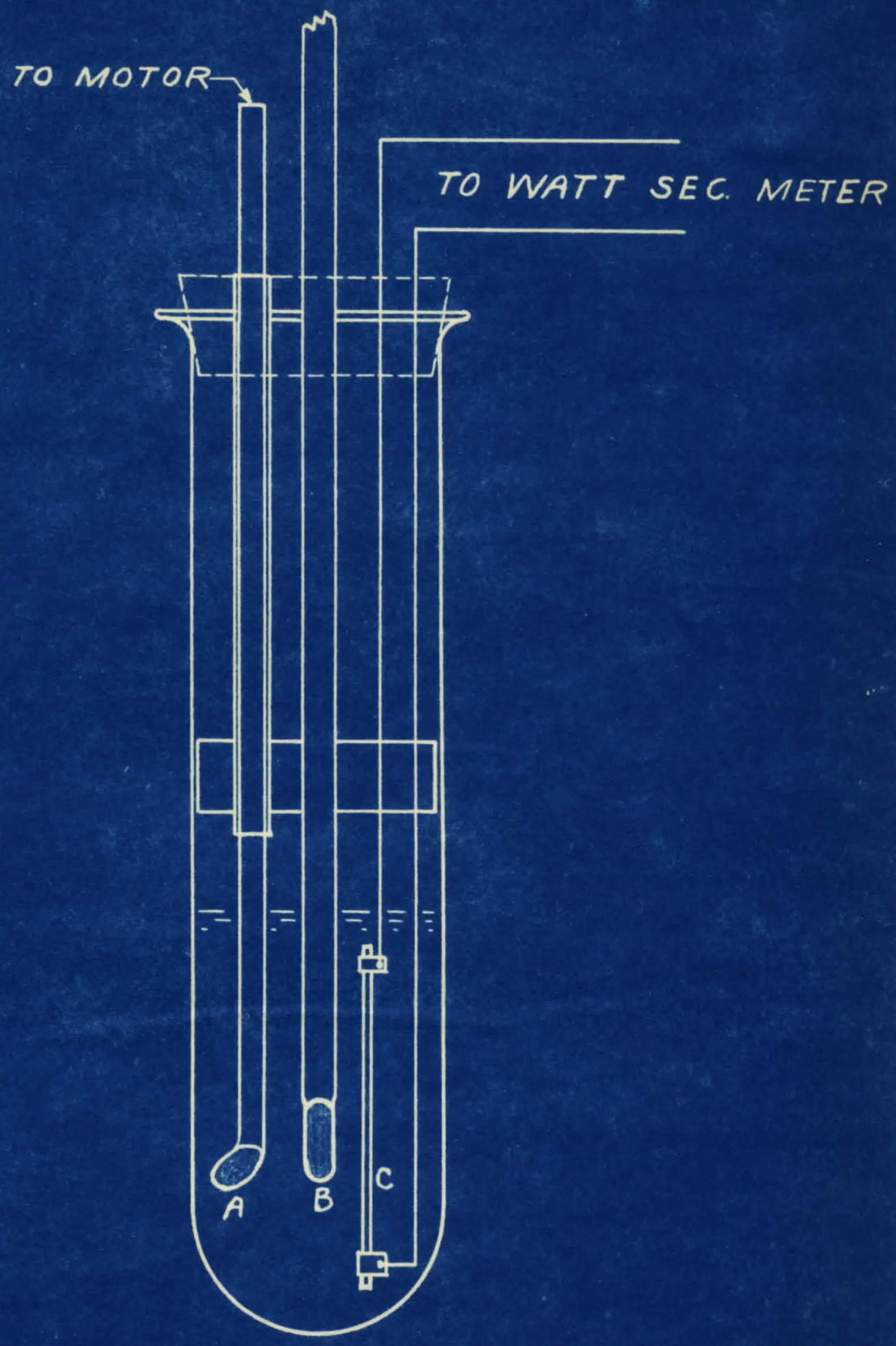

FIG.2

SPECIFIC HEAT A PPARATUS

A. STIRING ROD, B. THERMOMETER,

C. CARBON HEATING ELEMENT. 


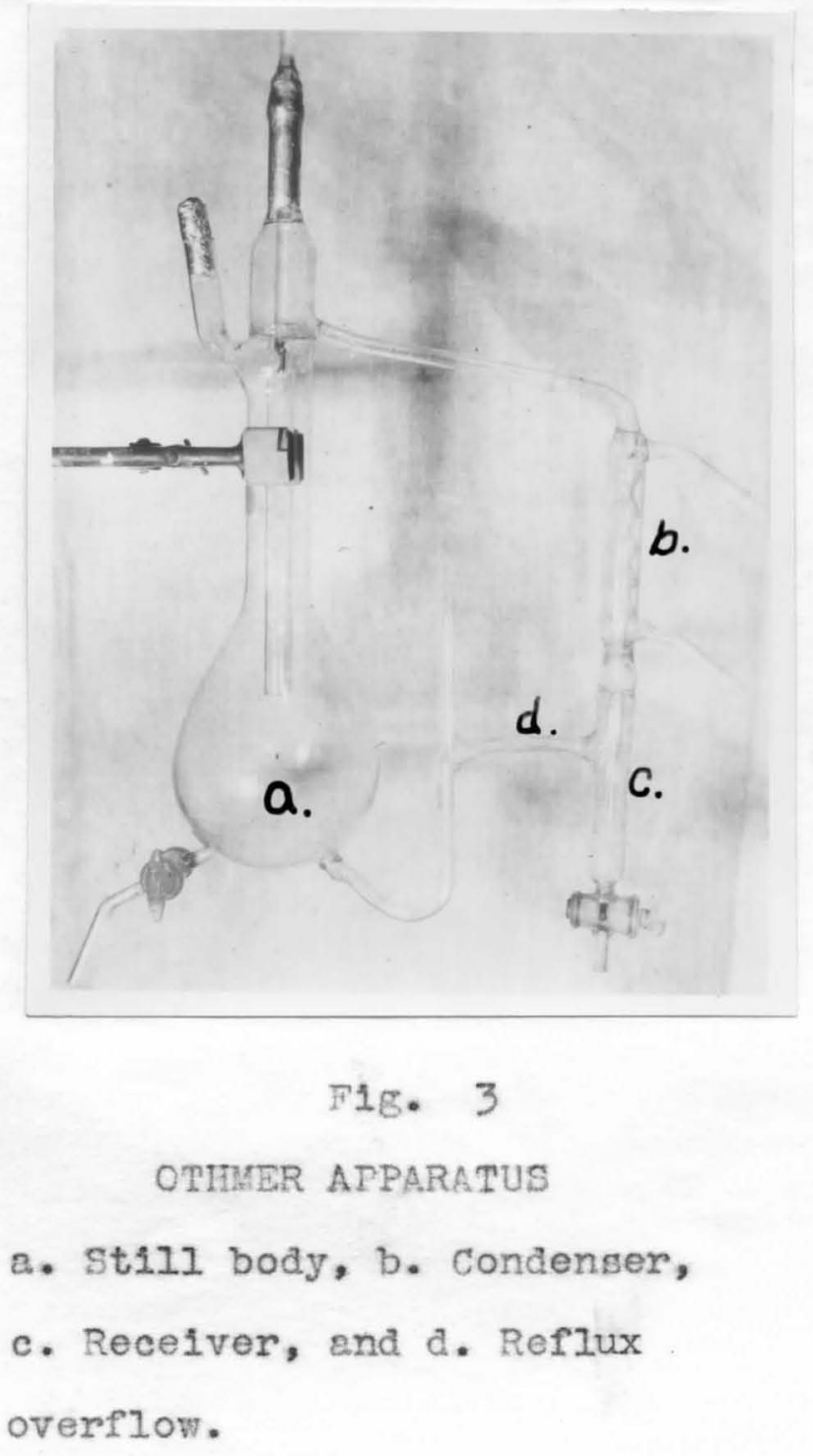


18 noted. After tro houre of constant temperature operation, in which time the liquid in the redelver 1s changed eight to ten times, the 11quid and vapor samples are taken. The pressure was maintalned at $760 \mathrm{mrn}$. mercury throughout the run. The composition of the samples was found by determining the refractive Index and dencity. The data from a prevloue investigation (1) wero used in preparing F1B. 4. The intersection of the conctant density 11 ne and constant refractive Index line locates a point on the triangular diagram Which reprecente the composition of the sample. Thus nolnt A represente a ample having a refractive index of 1.3900 and a deneity of 1.0200 . Its composition $1040.0 \%$ water, $33.5 \%$ glycerol, and $26.5 \%$ ethanol.

The thermometer uced wa a $0-200^{\circ} \mathrm{C}$. thermometer, callbrated by the Bureau of Standarda (No. 53360). The denelties of the vapor and liquld samples were determined using a westphal balanoe. An Abbe refractoneter (5) was used to obtnin the refractive index. Theee proertiee were run at $25^{\circ} \mathrm{C}$. using a constant temperature ath as described in a previous diasertation(1). VAPOR PRTCIRE AND B ILING FCINT. F1\%. 5 in a dagram of a modification of the cottrell anparatus (10). Bo11Ine polnte and vopor pressures wero de ermined in this apparatus. The omplo 18 admitted into the tube at $\mathrm{A}$ 
FIG. 4

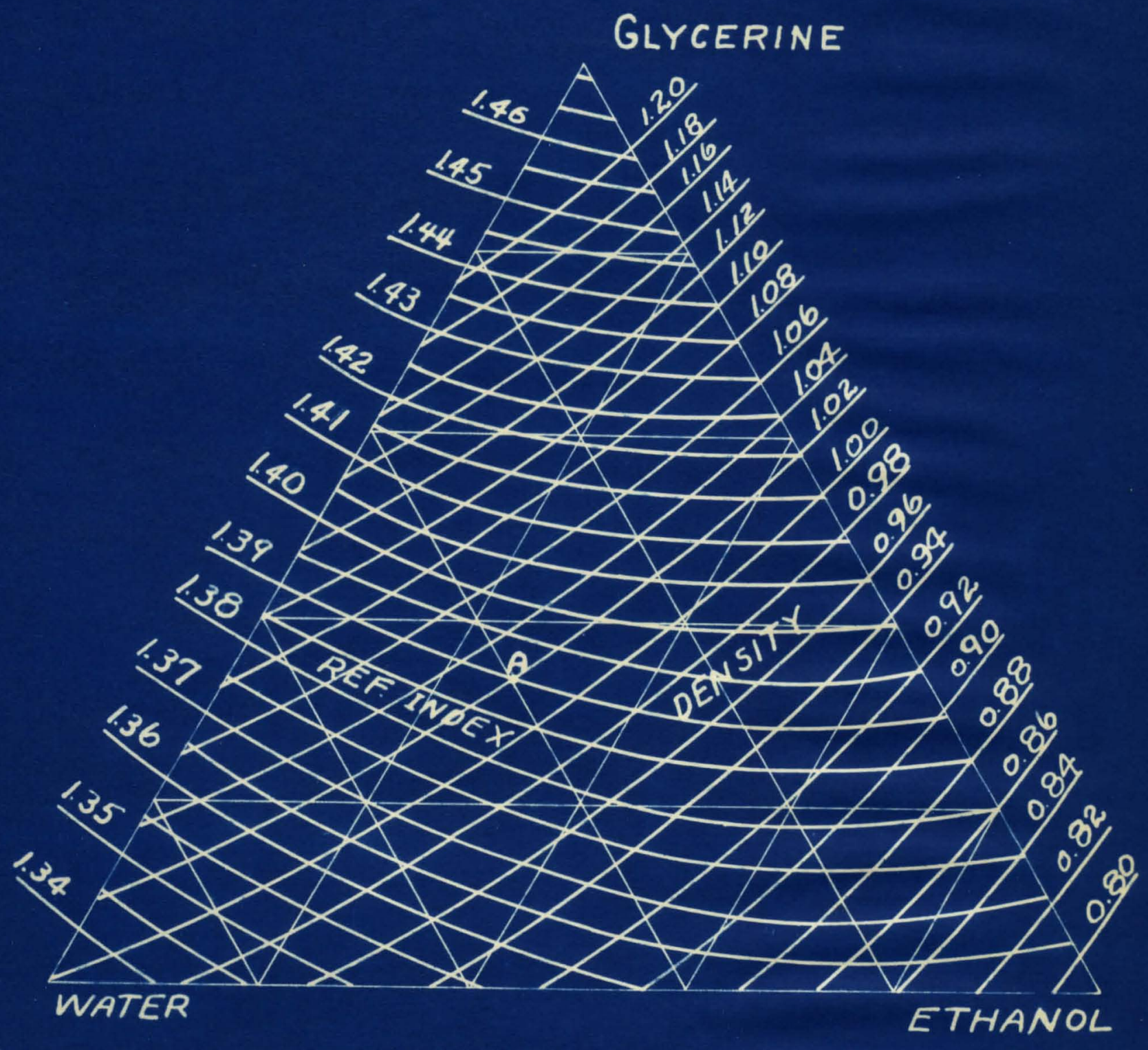




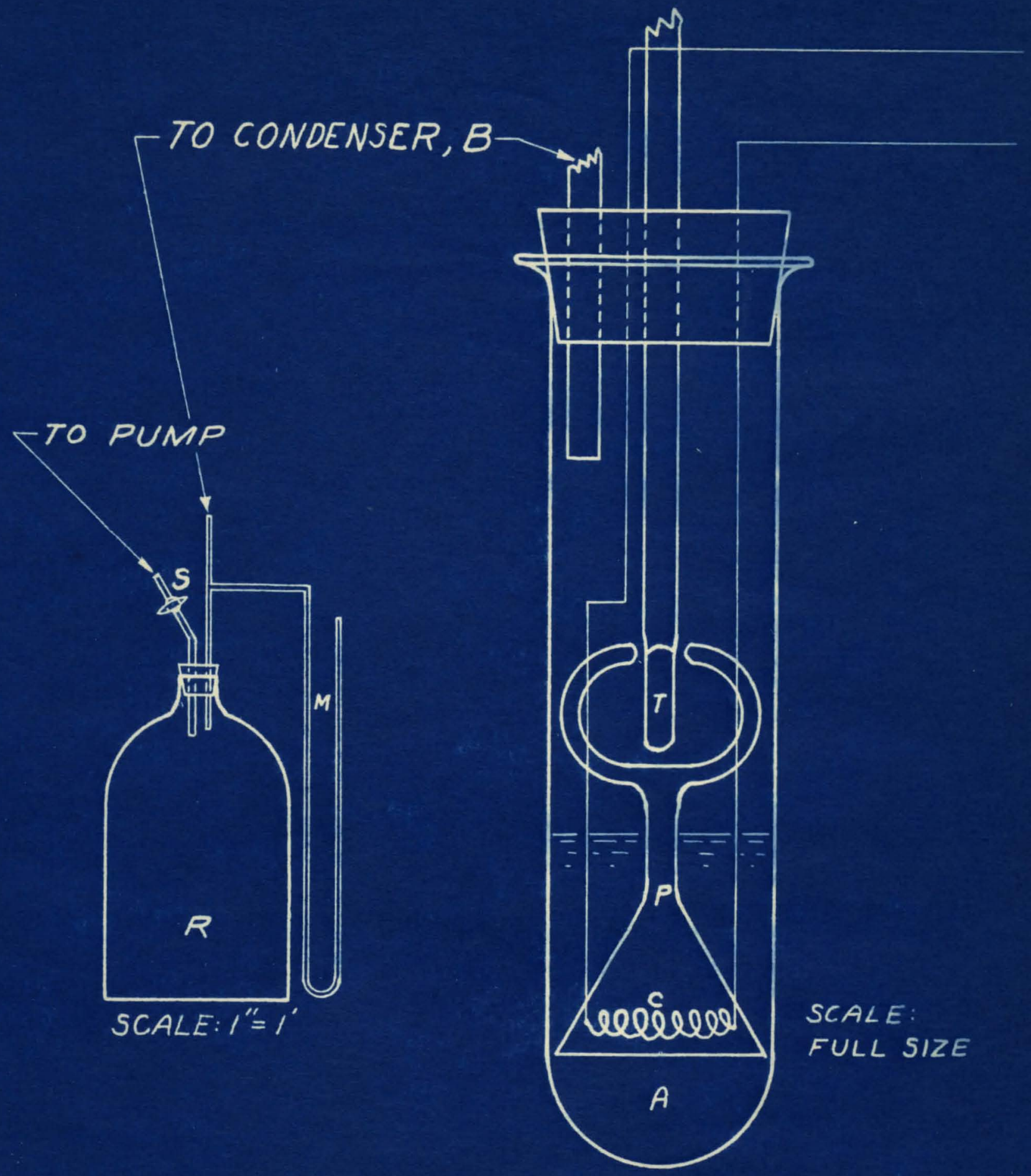

FIG. 5

BOILING POINT APPARATUS

$T$, THERMOMETER BULB, $P, P E R-$

COLATOR, C, HEATING COIL, A,

LIQUID SPACE, M, MANOMETER,

R, PRESSURE REGULATOR 
and the heating element. $c$, heate the liquid to bolling. As the liquid bo1lo it rige through the percolator, and 18 forced continuously upon the thermoter bulb, $t$. Any vapore that escape are condenced at $D$ and returned to the eystem $A$, and the cycle 10 repeated. The pressure on the syetem was kept congtent w1th the use of the recelver and manometer, shown in diagram.

To determine vapor pressure the stopcock, $a$, was opened to the euction, and the pressure on the system whe reduced to $150 \mathrm{~mm}$. mercury abcolute. The heatIng coll we turned on; and after continuous percolation and constant temperature and pressure were maintained, readinge were taken. The presure, calculnted by eubtractine the difference in levels of the mercury In the nanometer column from the barometer roaling, and the temperature, recorded by the thermometer, reprerent a notnt on a vapor precoure curve. The precsure is now changed by opening stopcock $\mathrm{g}$ and another such reading $1 \mathrm{~s}$ taken. When the prescure is $760 \mathrm{~mm}$. mercury, the temperature recorded is the bolling point. Thue, with this apparatuc, both bolling pointo and vapor pressures vere determined. The thermometer used was callbrated by comparison with a Bureau of Standard ' thermometer. A mercury barometer was used. Latent 
heats were calculated from the vapor presaure data using the Clauslus-clapeyron equation as discussed in Chapter II. 


\section{CHAPTER IV.}

EXEERIMENTAL 
EXIERIUENTAL

NATERIALs: Ethyl alcohol of the C. P. Erade was treated wh metali1c calclum and metallic sodium, then d1st111ed repeatedy.

Chemically pure glyoerine $0 . s$ alstilled repeatedly under reduoed preesure until a density deternination ueing a callbrated pycnometer chowed the abcence of water.

D1st111ed water was treated with potasslum permanganate to remove any ox1dante and then dist111ed. Treatment with brium hydroxide and successive diatiliations followed. The phyoleal proportieg of the reculting mater1als and value given by other experimenters are show in Table I.

PREPRATI OF OAPLES. The Samples were prepared on a welght percent basio in increments of ten per cent. The correct amount of Elycerine was added to a rround glaso stopered flack and the correct welght of othanol and woter edded oy means of buret ee (number of C.C. were calculated from a enelty determination). The compoeitions of the resulting elxty-s1x rample are shown in Table II. speciflc heats, bolling points, latent heats and vapor precsurec were determined for the sixty-o1x Samples. Both binoldal and triantular diarrams have been prepared for the flrgt two mentioned properties. Speciflo Heate, boling polnts, and latent heate for the system are given in Table III. 


\section{TIDE 1}

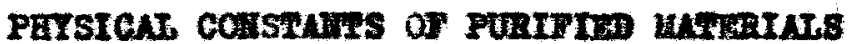

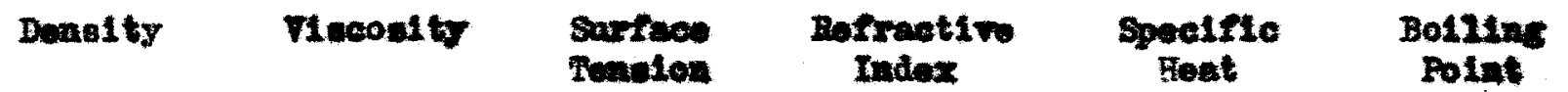

\begin{tabular}{|c|c|c|c|c|c|c|}
\hline Ethanol & $\begin{array}{l}0.7851 \\
0.78506(22) \\
0.78510(23)\end{array}$ & $\begin{array}{l}1.10 * \\
1.101(19)\end{array}$ & $\begin{array}{l}22.0 \\
22.03(13)\end{array}$ & $\begin{array}{l}1.3596 * \\
1.35941(15)\end{array}$ & $\begin{array}{l}0.536 \\
0.54(16)\end{array}$ & $\begin{array}{l}78.3 \\
78.4(27) \\
78.3(29)\end{array}$ \\
\hline Glyearino & $\begin{array}{l}1.2580 \cdot \\
1.2580(26) \\
1.25602(11)\end{array}$ & $\frac{934}{945(24)}$ & $\begin{array}{l}62.5 * \\
63.0(24)\end{array}$ & $\begin{array}{l}1.4729 \\
1.4730(4)\end{array}$ & $\begin{array}{l}0.555= \\
0.511(25) \\
0.589(25)\end{array}$ & $\begin{array}{l}289 \cdot- \\
290 \cdot(20)\end{array}$ \\
\hline Deter & $\begin{array}{l}0.99707 . \\
0.99707(18) \\
0.99707(1)\end{array}$ & $\begin{array}{l}0.893^{\circ} \\
0.894(17) \\
0.893(20)\end{array}$ & $\begin{array}{l}72.01 \\
72.0(16) \\
7.86(30)\end{array}$ & $\begin{array}{l}1.3332 \\
1.3325(21) \\
1.3333(9)\end{array}$ & $2.00^{\circ}$ & 2.00 \\
\hline
\end{tabular}

- mathor's expertmontal values.

- Tolver nocoptad zor allbretlon of instrumente.

- Aroorino decompoeen slonis at $200^{\circ} \mathrm{G}$. and above. 
TABIE II

GOMPOSITION OF SAMPIES

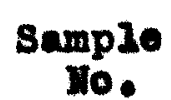

1

$2 \quad 200$

3

4

6

6

7

8

$\vartheta$

20

11

12

13

14

16

16

27

18

10

20

22

28

80

80
Wt. Pot.

alyoorol

200

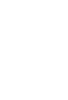

Wt. Pot.

Ethano2

200

10

20

30

40

60

60

70

80

90

70

60

50

40

30

20

20

20

90
Wt. Pot.

Wates

100

90

80

70

60

50

40

30

20

10

20

20

30

40

50

60

70

80

90 


\section{TABIF II oont ' $d$. \\ COMPOSITION OF SAUPIAS}

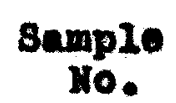

28

24

28

26

27

28

29

30

32

32

83

34

36

36

37

38

39

40

41

42

48

44

\begin{abstract}
qu. Pet.
aljeoraz
\end{abstract}

20

30

40

50

60

70

80

90

80

70

60

50

40

30

20

20

70

60

50

40

30

20
W. Pots.

Ethanol

80

70

60

50

40

30

80

10

20

10

10

20

20

30

10

40

10

60

10

60

30

70

10

80

20

10

80

20

20

30

20

40.

80

50

20

60 
TABLE II cont 'd.

\section{COMPOSITION OF SAMPLES}

\begin{tabular}{|c|c|c|c|}
\hline $\begin{array}{c}\text { Sample } \\
\text { Ho. }\end{array}$ & $\begin{array}{l}\text { Wt. Pot } \\
\text { alyooroi }\end{array}$ & $\begin{array}{l}\text { Wt. Pot. } \\
\text { Bthanod }\end{array}$ & $\begin{array}{c}\text { Wt. Pot } \\
\text { Wates }\end{array}$ \\
\hline 45 & 10 & 20 & 70 \\
\hline 46 & 60 & 30 & 10 \\
\hline 47 & 50 & 30 & 20 \\
\hline 48 & 40 & 30 & 30 \\
\hline 40 & 30 & 30 & 40 \\
\hline 60 & 20 & 30 & 50 \\
\hline 61 & 10 & 30 & 60 \\
\hline 62 & 50 & 40 & 10 \\
\hline 63 & 40 & 40 & 20 \\
\hline 54 & 30 & 40 & 30 \\
\hline 56 & 20 & 40 & 40 \\
\hline 56 & 20 & 40 & 50 \\
\hline 57 & 40 & 50 & 10 \\
\hline 58 & 30 & 50 & 20 \\
\hline 59 & 20 & 60 & 30 \\
\hline 60 & 10 & 50 & 40 \\
\hline 61 & 30 & 60 & 10 \\
\hline 68 & 20 & 60 & 20 \\
\hline 63 & 20 & 60 & 30 \\
\hline 64 & 20 & 70 & 10 \\
\hline 68 & 10 & 70 & 20 \\
\hline 66 & 10 & 80 & 20 \\
\hline
\end{tabular}




\section{Table III}

Physical Froperties

Sample No. Soc1f10 Heat

1.

2.

3.

4.

5.

6.

7.

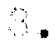

9.

10.

11.

12.

13.

14.

15.

16.

17.

1 .

19.

20.

21.

2 ?.
0.537

1.00

1.036

1.040

0.995

0.964

0.915

0.959

0.784

0.700

0.618

0.579

0.610

0.665

0.715

0.770

0.310

0.70

0.930

0.967

0.550
0.555
Boll1ng Latent Polnt ${ }^{8}$. Heat Cal./Mol

$\begin{array}{rr}70.3 & 9.736 \\ 239.0 & 17.740 \\ 100.0 & 9.74 \\ 91.7 & 9.920 \\ 77.3 & 10,150 \\ 4.7 & 10,150 \\ 3.2 & 9,330 \\ 1.8 & 9,330 \\ 0.3 & 9,920 \\ 70.1 & 9.742 \\ 79.2 & 9.736\end{array}$

73.4

10,392

142.0

10,057

121.1

10,011

113.5

9.965

109.9

9,920

106.1

9,920

104.0

9,220

103.0

9,920

101.3

9.920

101.0

$9 ., 30$

79.3

9.742 
Table III (continued)

\begin{tabular}{|c|c|c|c|}
\hline Sample No. & $\begin{array}{l}\text { Speciflc } \\
\text { Heat }\end{array}$ & $\begin{array}{l}\text { Boling } \\
\text { point }\end{array}$ & $\begin{array}{l}\text { Latent } \\
\text { Heat Cal./Mol }\end{array}$ \\
\hline 23. & 0.550 & 80.5 & 9,656 \\
\hline 24. & 0.549 & 31.7 & 9.656 \\
\hline 25. & 0.543 & 2.9 & 9,656 \\
\hline 26. & 0.550 & 34.6 & 9.4 \\
\hline 27 & 0.549 & 36.2 & 9,366 \\
\hline 23 & 0.549 & 99.3 & 9.247 \\
\hline 29. & 0.551 & 97.0 & 9,169 \\
\hline 30. & 0.552 & 119.4 & 9.093 \\
\hline 31. & 0.51 & 103.4 & 9,656 \\
\hline 32. & 0.622 & 97.3 & 9,614 \\
\hline 33. & 0.675 & 94.7 & 9,530 \\
\hline 34. & 0.741 & 93.4 & 9,30 \\
\hline 35. & 0.790 & 92.5 & 9,742 \\
\hline 36. & 0.356 & 92.1 & 9.075 \\
\hline 37. & 0.921 & 91.3 & 9.875 \\
\hline 39 & 0.966 & 91.6 & 9,488 \\
\hline 39. & 0.538 & 90.6 & 9.530 \\
\hline 40. & 0.635 & 33.6 & 9,920 \\
\hline 41. & 0.631 & 37.5 & 9,330 \\
\hline 42. & 0.735 & 87.1 & 9,656 \\
\hline 43. & 0.010 & 7.0 & 9,656 \\
\hline 44. & 0.335 & 37.0 & 9,920 \\
\hline
\end{tabular}




\section{Table III (Continued)}

\begin{tabular}{|c|c|c|c|}
\hline Cample No. & $\begin{array}{l}\text { Specific } \\
\text { Heat }\end{array}$ & $\begin{array}{l}\text { Bolling } \\
\text { Polnt }{ }^{\circ} \text {. }\end{array}$ & $\begin{array}{l}\text { Latent } \\
\text { Heat Gal./Mol }\end{array}$ \\
\hline 45. & 0.953 & 37.1 & 9.742 \\
\hline 46. & 0.591 & 26.3 & 9.76 \\
\hline 47. & 0.644 & 35.1 & 9,736 \\
\hline 4 & 0.690 & 34.5 & 9.030 \\
\hline 49. & 0.754 & 94.3 & 9.614 \\
\hline 50. & $0.9 \geq 1$ & 34.3 & 9,614 \\
\hline 51. & 0.910 & 84.5 & 9.614 \\
\hline 52. & 0.592 & 34.1 & 9,614 \\
\hline 53. & 0.642 & 33.4 & 9,656 \\
\hline 54. & 0.702 & 33.0 & 9.330 \\
\hline 55. & 0.775 & 32.9 & 9,614 \\
\hline 56. & 0.060 & 32.9 & 9.330 \\
\hline 57. & 0.591 & 32.6 & 9.699 \\
\hline 50 & 0.643 & 32.0 & 9.330 \\
\hline 59. & 0.720 & 31.9 & 9,330 \\
\hline 60. & 0.309 & 31.7 & 9,330 \\
\hline 61. & 0.592 & 1.5 & 9,920 \\
\hline 62. & 0.660 & 30.8 & 9.920 \\
\hline 63. & 0.741 & 30.8 & 9,920 \\
\hline 64. & 0.610 & 30.4 & 9,920 \\
\hline 65. & 0.677 & 30.2 & 9,920 \\
\hline 66. & 0.616 & 79.4 & 9,920 \\
\hline
\end{tabular}




\section{SPECIFIC HEATC}

The apparatue ueed in deteruining specific heats 1s ohom 1n F1g. 2. Experlmentally, the values of $\Delta t$, $\pi$, and $\mathrm{B}$ are obtained, where

$$
\begin{aligned}
& \Delta t \text { - temperature rise of cample, }{ }^{\circ} \text {. } \\
& w \text { - watt second }=14.136 \text { eram calories and } \\
& \text { E - grams of cample used. }
\end{aligned}
$$

Speciflc Heats are calculated fron the experimental data by means of the equation:

$\frac{\frac{w}{4.18 b}-\mathrm{K} \Delta t}{\mathrm{~B} \Delta t}=$ ep. ht. In Cal. per eram per ${ }^{\circ} \mathrm{C}$.

Where $K$ 1s the calorineter constant (7.42) and 4.136 electrical equivalent of heat. $\Delta t \cdot h$ represents amount of heat lost to apparatus. NML CALCULAIC: Values elven a re those obtained for Sample No. 47:

$$
\begin{aligned}
\Delta t & =6.00^{\circ} \mathrm{C} \\
w / 4.106 & =143.0 \text { gram calories } \\
K \Delta t & =44.50 \text { calories } \\
g & =25.42 \text { Grams }
\end{aligned}
$$

Substituting in formula one obtains:

$$
\frac{143.0-44.5}{25.42 \times 6.00}-\frac{0.5}{152.52}=\cdot 644
$$

Tris is a sample of the calculations used for determining the opecific heate of the sixty-six camples, the results of which are shown in Table III. 
Fig. 6 is a binoidal graph which shows the specific hest of the system plotted against composition. The specific heats of the water-ethanol binary system reach a maximum at eighty percent water; then the values drop on a smooth curve to that of pure ethanol. The values of the binary system glycerine-ethanol lie on a smooth curve which is almost a straleht line. The constant percent glycerine lines show a curvature sinilar to that of the ethanol-water curve: however the sixty percent and higher lycerine curves amroach a straicht line.

The triangular diagram of Fig. 7 is another graph of the properties. Each line on this graph joins points which represent conpositions hevine the same onecific heat. This aiacran is prepored from Fig. 6.

The curvature of the lines in Fig. 7 can be explained by the fact that the constant percent glycerine lines and the ethanol-water lines reach maximums. 


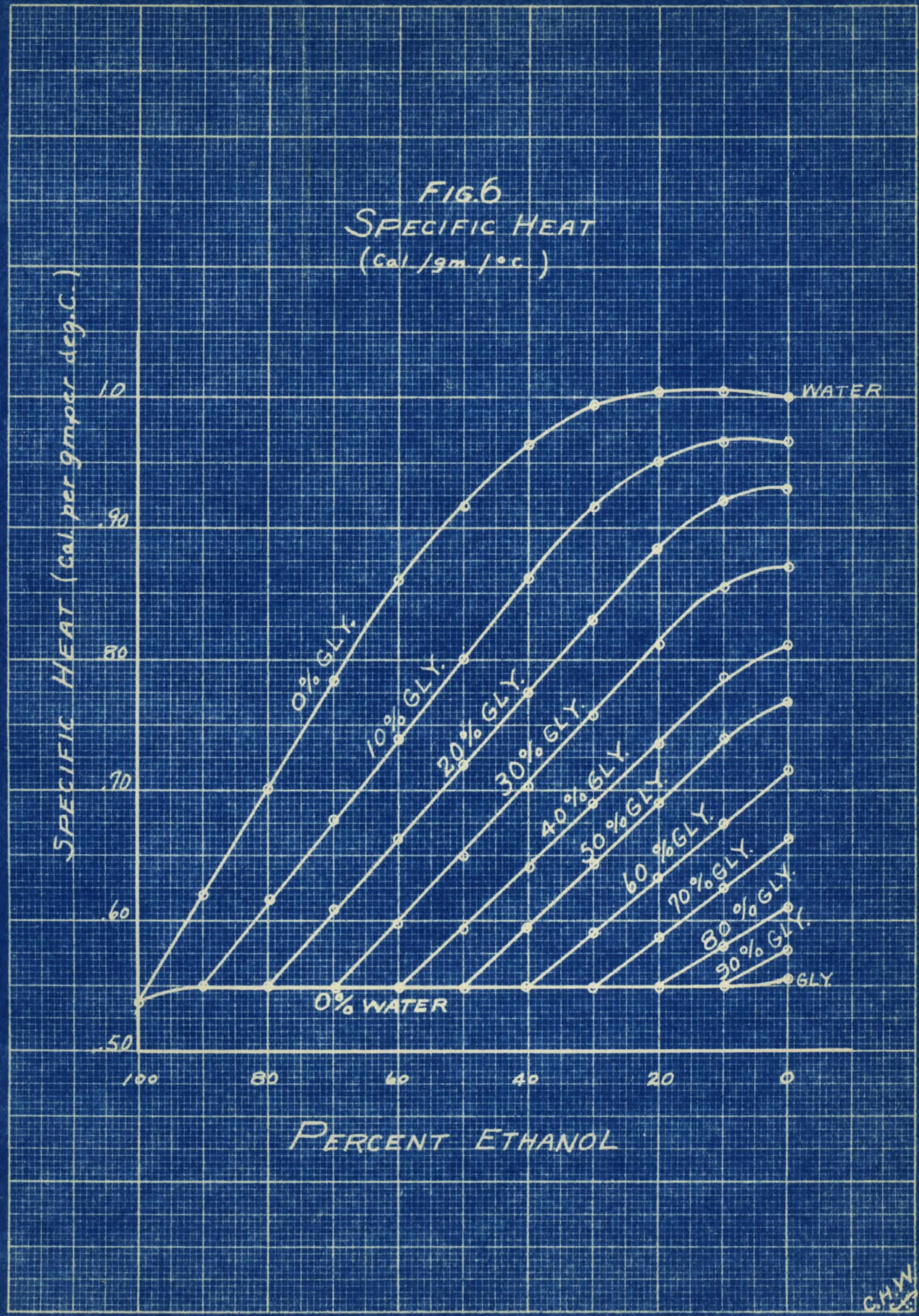


FIG. 7

SPECIFIC HEAT

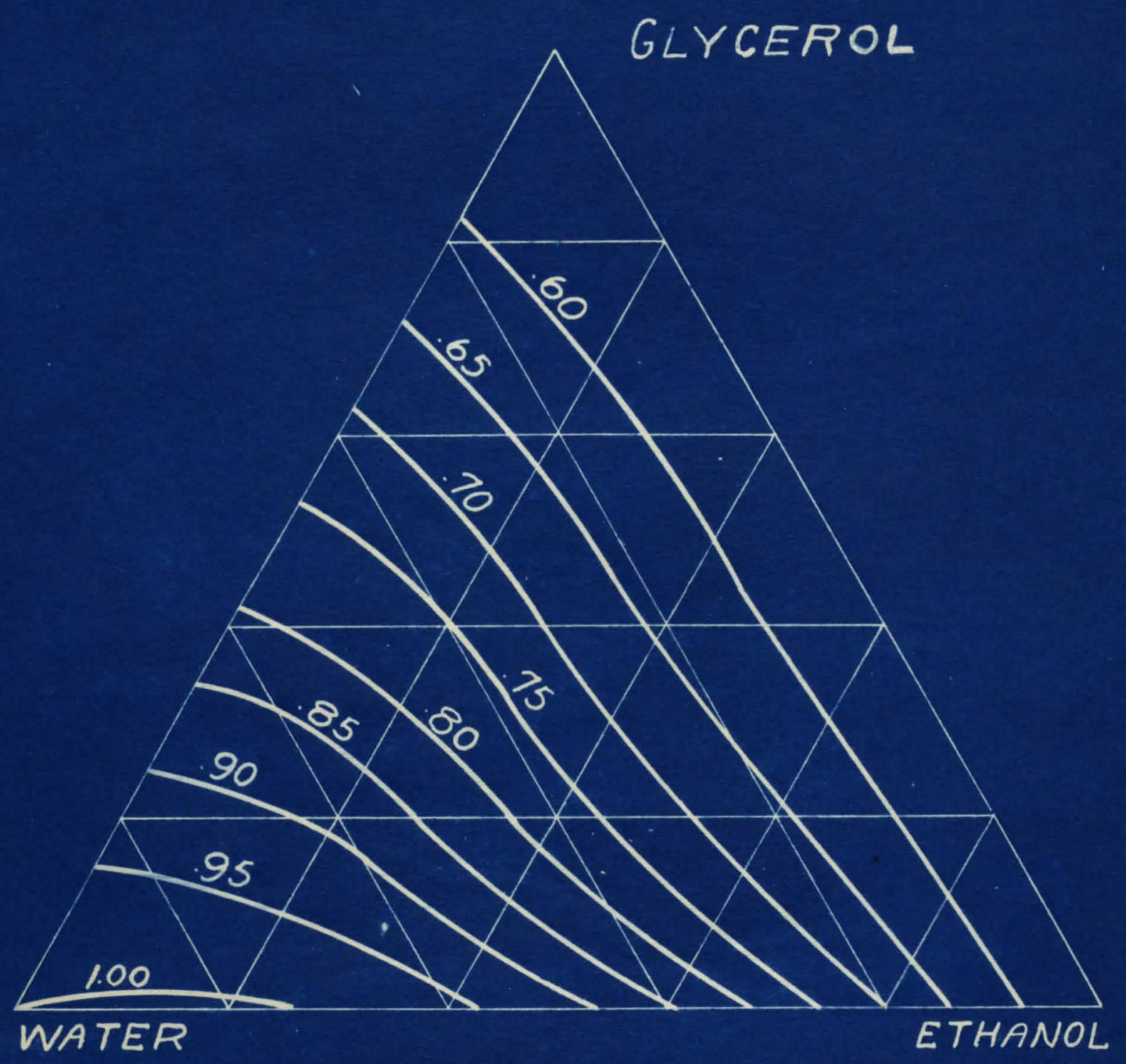




\section{BOILING POINTS}

The bolline polnte of pure ethanol, water and glycerine are $7.3,100.0$, and $290^{\circ} \mathrm{C}$ respectively. The vapor prescure of glycerine (bee F1g.1) 16 lese than flve mm. mercury at $100^{\circ} \mathrm{C}$. and is only $45 \mathrm{~mm}$. mercury at $200^{\circ} \mathrm{C}$. From these two facto it can be seen that the glycerine, in smell percentace, w111 not have a very great effect on the bolling polnt of the ternary syetem. The graph of the bollIng points (Fig.) showe this to be true for camples whose lycerine vercentace is rifty percent and lesc. Especinily true 15 thif estenent when the sample containe ten percent or more of ethanol. The bolilne points for the hinary system, ethanol-viter l1e on a smooth curve between the values for the pure components. The constant percent glycerine lines have a curvature Amilar to that of the latter, but are displec d to the rieht as the glyoerine percentace is increased. The triangular diacrom (F1E.9), containing the conetant bolline point lines show the latter to be almost parallel to the conetant percent ethanol lines. Th1s showe that the ethanol content overna the bolling point. 


$$
\text { Fro. } 8
$$

BoILING poINT diagram

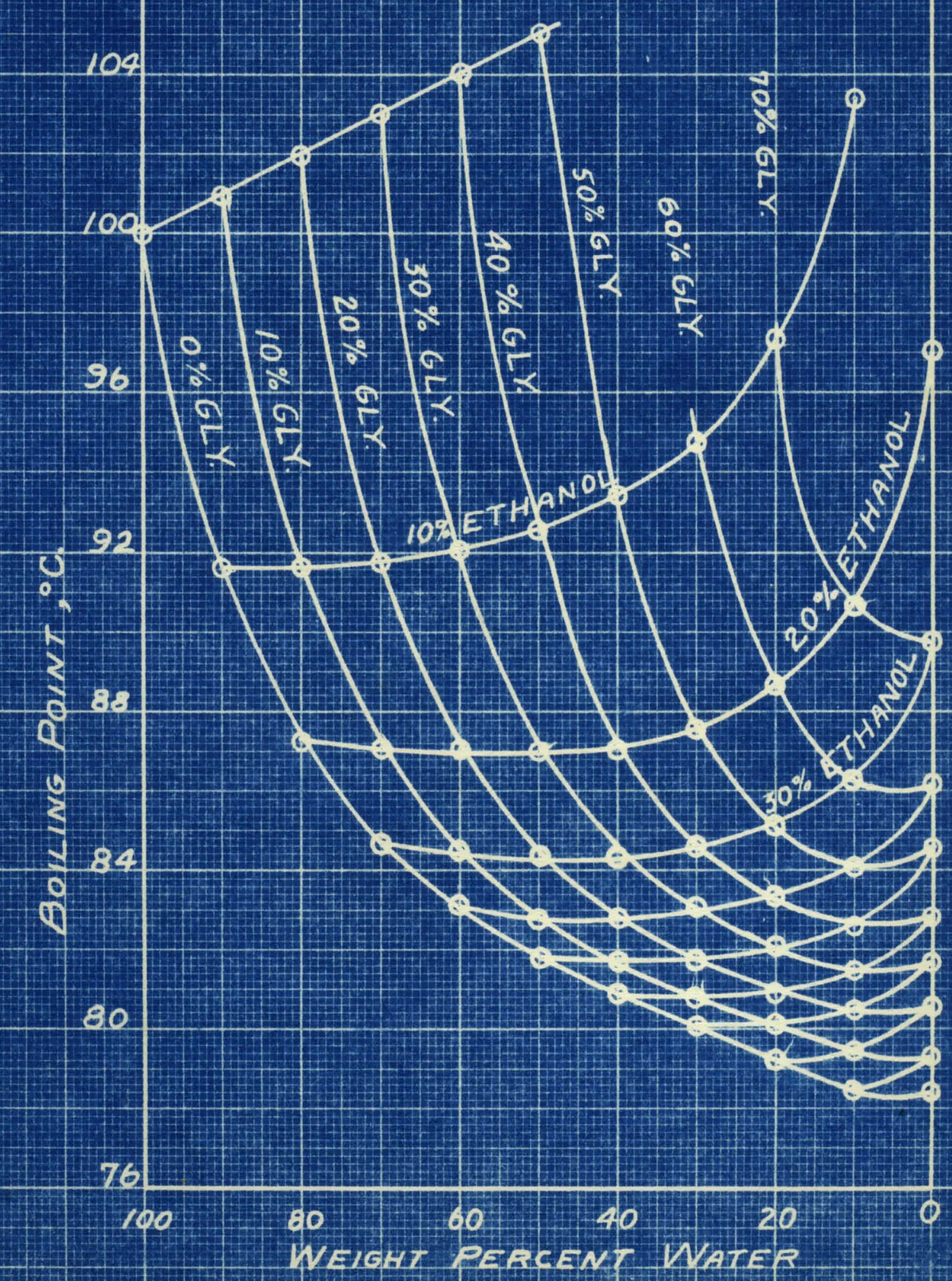


FIG. 9

BOILING POINT DIAGRAM

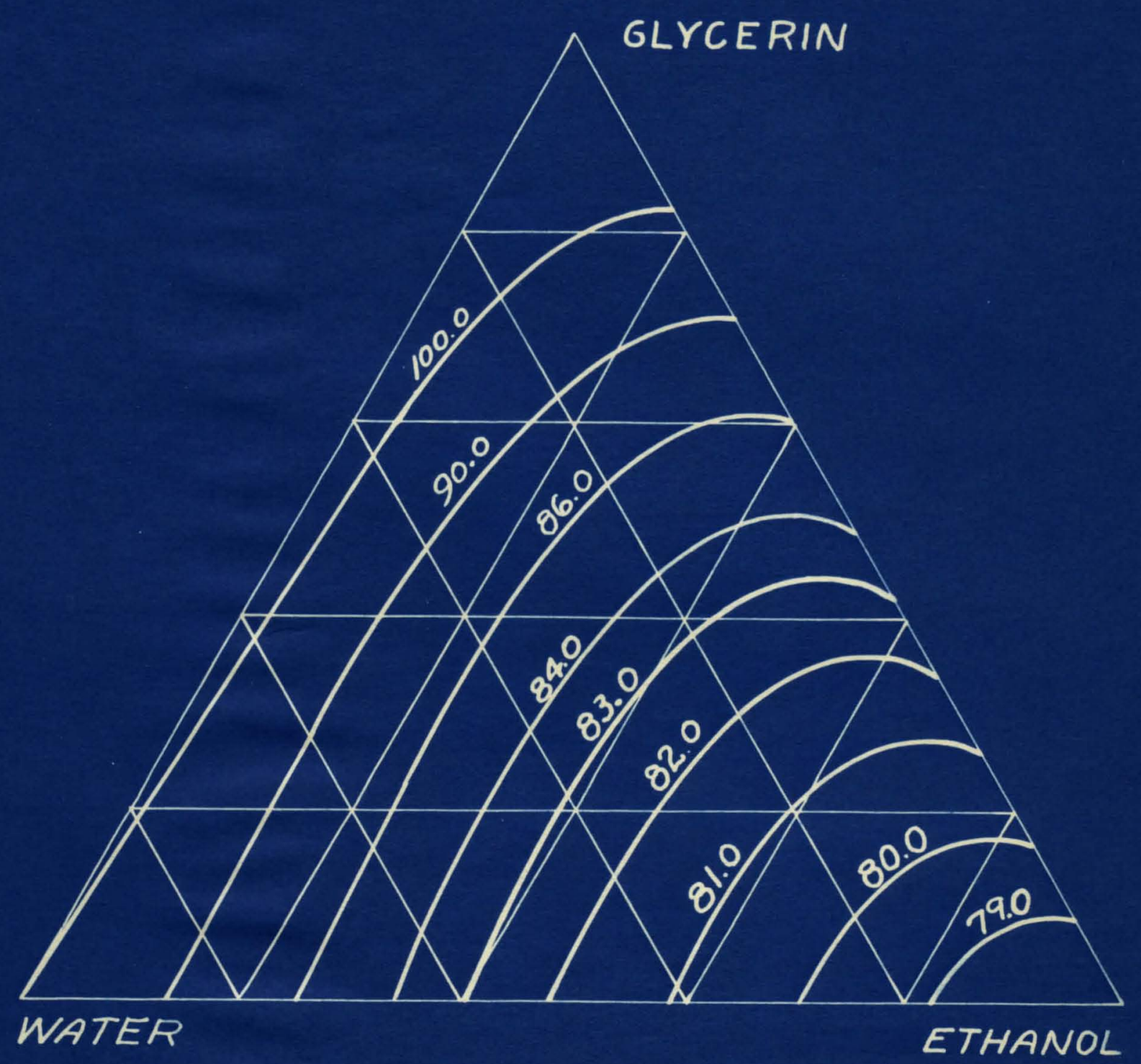




\section{VAFOR PREMUTH?}

Vapor preceure data for the s1xty-s1x samples are chom in Table IV. Thece data for the blnary systeme ethanol-vater and rater-glycerin are shown graphlcally in FIg. 10. Th1E Eroph show the effect that ethanol and glycerin exert upon the vapor preagure of the systema. As the percent ethanol is 1ncreased, the vapor preseure Inec are euccessively displaced to the right of the vapor presure line for water. This weans that, at alven temperature, the vapor preseure of the ethanol-mater corles is renectively increased with increace in ethanol content. The vapor pressure Iines to the left of that for woter are those for the glycerinwater cycten. The glycerin ercentare incroace ar the distance of the vapor pregeure lines from that of water 1s increated. Thus, it chow thet ony increase in glycerin nercentace decreaces th vopor preseure of the eystem.

Figures 11 and 12 show vapor pressure ines for come of the amples of the ternary system. Others have been omltted because they colnclde with those shom in the flgures: but in all cas the rlce of the vapor pressure due to the glycerin 10 amarent. 
Table IV

Vapor Preseure Data

Cample No. Vapor Prescure Temperature Feciprocal min. mercury degrees cent. of $A b s$. Temp. $\times 1000$

1.

115.0

303.1

454.0

607.3

760.0

905.5

2.

21.0

550.0

760.0

916.0

3.

23.0

100.0

200.0

395.0

605.0

760.0

4.

120.0

432.0

572.0

760.0

5.

110.0

451.0

600.0

760.0

6.

20.6

474.1

626.6

760.0

7.

276.6

467.7

640.7

760.0

902.7

$$
\begin{gathered}
54.73 \\
76.1 \\
36.1 \\
93.9 \\
100.0 \\
105.0
\end{gathered}
$$

55.1
70.4

78.3

3.1

170.0

227.0

246.0

263.0

2.0

29.0

49.0

77.3

4.3

91.7

44.2

74.2

1.3

7.3

$60 . ?$

72.9

79.7

4.7

59.2

71.2

7.9

33.2

37.8
3.052

2.365

2.75

2.726

2.601

2.746

3.04

2.912

2.347

2. 0 ?

2.257

2.000

1.927

1.848

1.302

1.779

3.106

2. 55

2. 99

2.742

3.153

2.880

2.322

2.776

2.995

2. 991

2. 35

2.796

3.010

2.907

2.42

2.30

2.772 


\section{Table IV (continued). \\ Vapor Fregeure Data.}

fample No. Vapor Tressure Temperature Reclprocal

$\mathrm{mm}$. mercury degrees cent. ${ }_{\mathrm{x}} \mathrm{Abs}$. emp.

8.

140.0
306.7
560.2
760.0
902.2

44.1

60.3

74.4

32.1

36.4

9.

154.7

29.

563.3

760.0

905.3

10.

170.5

297.0

555.5

760.0

917.5

11.

71.0

20.5

552.0

760.0

907.5

12.

77.0
27.0
562.0
760.0
913.0

44.3

58.9

73.6

80.3

35.7

46.9

5.0

72.3

0.1

35.0

3.154

2. 79

2. 16

2.735

30.1

56.0

71.3

79.2

33.7

3.147

3.013

2.382

2. 24

2.739

3.126

3.116

2. 96

2.332

2.793

30 .

55.7

70.1

7.4

32.2

3.299

3.040

2.905

2. 339

2. 04

13.

145.0

294.0

476.0

760.0

910.0

14.

145.2

29.2

472.2

760.0

39. 7

90.0

110.0

120.1

141.

14.6

3.390
3.043
2.90
2.45
2.15

2.757

2.611

2.493

2.411

2.372

75.9

$2 . .66$

2.732

106.

120.1

2.633

2.53

125.5

2.509 


\section{Table IV (continued) \\ Vapor Preecure Data.}

Sample No. Vapor Presure mm. mercury

15.

16.

17.

13.

19.

20.

21.

$$
\begin{array}{r}
141.7 \\
290.7 \\
42.2 \\
760.0 \\
91.7 \\
140.0 \\
300.1 \\
430.0 \\
760.0 \\
93.0
\end{array}
$$

140.2

20.7

479.7

760.0

399.7

146.2

290.2

479.7

760.0

390.7

142.5

291.5

430.5

760.0

397.0

133.0

293.0

433.0

760.0

$897: 0$

147.0
Temperature Reclprocal degrees cent. of $\mathrm{Abs}$. Temp. $\times 1000$

292.0
43.0

760.0

$91 \div .5$
6.9

6.1

100.1

113.3

117.4

65.3

3.6

96.9

109.7

114.3

63.9

79.7

92.9

106.1

111.0

62.1

77.3

90.1

103.9

10.6

60.1

77.2

90.2

102.9

107.6

60.0

76.4

90.0

101.3

59.9
75.5
10.4
100.9
105.9
2.925

2.75

$2.6 ? 0$

2.59

2.562

2.957

2.204

2.704

2.613

2.579

2.968

2.835

2.733

2.734

2.604

2.931

2.351

2.743

2.653

2.621

2.995

2. 356

2.753

2.661

2.623

3.001

2.363

2.762

2.66

2.637

3.001

2. 69

2.767

2.674

2.639 


\section{Table IV (continued) \\ Vapor Presaure Data}

Sample No. Vapor Preseure Temperature Reciprocal m. mercury

degrees cent. of Abs. Temp.

22.

$$
\begin{array}{r}
86.0 \\
29.0 \\
55 \% .0 \\
760.0 \\
399.0
\end{array}
$$

23.

140.0

296.0

555.1

760.0

393.5

24.

$$
\begin{array}{r}
4.0 \\
297.0 \\
569.5 \\
760.0 \\
900.0
\end{array}
$$

25.

0.0

310.0

577.5

760.0

94.5

26.

255.5

430.0

57.5

760.0

904.0

27.

21.6

461.6

55.6

760.0

28.

$$
\begin{array}{r}
2.02 .0 \\
44.0 \\
50.0 \\
760.0 \\
992.0
\end{array}
$$

33.0

56.6

71.6

79.3

33.7

42.5

53.1

72.3

30.5

35.0

$\times 1000$

3.263

3.034

2.902

2.93

2.304

3.175

3.021

2. 90

2.327

2.793

34.0
59.1
74.4
91.7
6.4

3.257

3.011

2.37

2. 19

2.703

34.0

61.1

75.

2.9

7.2

3.257

2.993

2. 367

2. 10

2.776

57.8

69.9

77.3

84.6

9.5

3.023

2.916

2. 51

2.796

2.753

60.9

72.5

79.2

36.1

2.995

2. 95

2.339

2.74

63.3

74.9

2.1

9.8

94.2
2.973

2. 74

2. 16

2.757

2.724 
Table No.IV (continued)

Vavor Pressure Data

Sample No. Vapor preesure ma. mercury

Temperature Reciprocal

degrees cent. of Abs. Temp $\times 1000$

29.

$$
\begin{array}{r}
157.5 \\
357.0 \\
557.5 \\
760.0 \\
900.0
\end{array}
$$

30.

31.

32.

142.5

29.5

430.5

760.0

909.5

139.5

295.0

40.5

760.0

906.0

142.1

296.5

473.5

760.0

90 . 0

33.

144.5

291.0

40.0

760.0

904.0

34.

143.1

289.1

477.6

760.0

904.6

35.

145.2

295.2

$473: 7$

904.7

$$
\begin{array}{r}
61.4 \\
76.6 \\
90.4 \\
97.0 \\
106.3
\end{array}
$$

70.4

50.5

103.4

11.5

127.7

61.0

76.7

83.5

103.2

107.3

54.

70.

34.2

97.3

102.2

54.2

70.6

32.

94.7

100.8

53.6

69.0

31.0

93.4

93.6

52.2

6.4

79.7

97.4
2.990

2.361

2.752

2.702

2.637

2.912

2.751

2.657

2.555

2.495

2.994

2.360

2.766

2.653

2.626

3.051

2.909

2.300

2.701

2.665

3.057

2.911

2.327

2.735

2.675

3.062

2.924

2. 24

2.750

2.691

3.076

2.930

2.135

2.736

2.700 
Table IV (continued)

Vapor Prescure Data

Sample

No.
Vapor Fresture

mo. mercury
Temperature

deg. cent.
Reclorocal

of $\mathrm{Ab}$. Temp. $\times 1000$

$$
\begin{aligned}
& 3.060 \\
& 2.934 \\
& 2.937 \\
& 2.739 \\
& 2.702
\end{aligned}
$$

3.070

2.932

2.334

2.742

2.704

3.

143.7

293.7

483.2

760.0

903.2

149.0

292.0

488.5

760.0

906.0

39.

143.0

293.0

435.0

760.0

900.0

40.

145.5

29.0

435.0

760.0

907.0

41.

146.5

24.0

433.0

760.0

906.0

42.
52.7

63.0

79.9

91.

96.8

53.2

66.7

79.3

91.6

96.2

49.3

65.6

90.6

95.1

49.5

65.1

76.7

23.6

92.4

43.7

63.2

75.0

7.5

92.4

50.0

63.3

74.8

87.1

91.6
73.1
3.066

2.944

2.834

2.740

2.709

3.098

2.953

2.843

2.752

2.717

3.101

2.953

2. 60

2.765

2.737

3.103

2.935

2. 373

2.747

2.737

3.096

2.974

2.875

2.777

2.743 
Table IV (continued)

Vanor Freenure Data

Sample

43.

44.

45.

46.

47.

43.

49.

Vapor Preceure

mo. merc ry

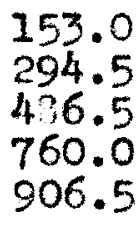

152.5

297.5

437.5

760.0

396.0

146.5

293.5

497.5

760.0

902.5

146.5

293.5

47.5

760.0

909.0

140.5

233.0

471.0

760.0

902.5

143.5

239.0

471.0

760.0

893.0

139.5

24.0

467.5

760.0

907.5
Temperature

dog. cent.

49.7

63.7

75.7

7.0

92.2

50.3

64.3

75.9

77.0

91.6

49.5

64.2

75.8

3.1

91.8

46.5

62.2

74.3

6.3

91.6

46.3

60.7

72.9

5.1

39.5

46.3

61.1

72.4

4.5

39.1

45.7

60.5

72.0

34.5

9.2
Rectrocal

of Abe. Temp. $\times 1000$

3.059
2.970
2.063
2.730
2.738

3.093

2.965

2.367

2.730

2.753

3.101

2.966

2. 367

2.777

2.741

3.130

2.933

2. 79

2.74

2.743

3.132

2.997

2. 91

2.793

2.759

3.132

2.994

2. 95

2.797

2.762

3.13

2.999

2.99 ?

2.797

2.761 


\section{Table IV (continued) \\ Vapor Preesure Deta}

Tample
No.

Vapor Preseltre $\mathrm{mm}$. mercury

Temperature des. cent.

50.

51.

136.4

21.4

472.4

760.0

910.4

$$
\begin{aligned}
& 135.0 \\
& 290.5 \\
& 476.5 \\
& 760.0 \\
& 929.5
\end{aligned}
$$

52.

146.0

303.0

433.0

760.0

53.

157.7

303.7

760.0

997.7

54.

14.0

305.6

490.0

760.0

927.5

55.

277.

43.

577.3

760.0

901.9

56.
45.3

60.3

72.2

04.3

9.1

45.0

61.0

72.5

4.5

39.8

46.4

61.6

72.6

34.1

$47 \cdot 1$

60.3

72.2

23.4

90.3

45.5

60.3

72.0

3.4

$33 \cdot 4$

59.4

63.5

76.5

33.3

33.7

49.6

66.1

75.0

32.3

27.0
Reclprocal of $A B s$. Temp $\times 1000$

3.142
3.000
2.397
2.799
2.762

3.145

2.994

2.95

2.797

2.756

3.131

2.939

2. 94

2.301

3.124

2.996

2. 997

2.306

2.749

3.139

2.996

2. 99

2. 909

2.767

$3.00 ?$

2. 928

2. 361

2. $: 03$

2.765

3.100

2.949

2. 374

2. 11

2.777 
Table IV (continued)

Vapor Preonure Data

Cample
0

57.

59.

53.

60.

61.

62.

63.

Vapor Prescure $\mathrm{mm}$. mercury

202.5

379.0

533.0

760.0

903.5

219.3

37.3

561.3

760.0

900.3

201.9

372.9

592.4

760.0

910.4

242.5

412.5

567.0

760.0

795.0

276.5

404.5

591.5

760.0

900.5

223.0

398.0

570.5

760.0

177.0

370.0

561.5

760.0

323.5
Tempe ature

deg. cent.

51.6

$65 \cdot 3$

75.6

32.6

7.7

52.9

65.0

74.2

82.0

6.4

51.2

64.6

75.3

81.0

6.9

54.9

66.7

74.3

1.7

26.0

56.4

65.5

74.6

0.9

85.3

53.9

65.1

73.2

30.8

47.5

634

73.2

0.3

$34 . ?$
Reciprocel of $\mathrm{Abs}$. Temp $\times 1000$

3.011
2.957
2.063
2.012
2.777

3.063

2.959

2.330

2.310

2.73

3.035

2.962

2. 71

2.310

2.779

3.049

2.944

2.379

2.320

2.76

3.036

2.954

2. 877

2.25

2.791

$3.06 ?$

2.950

2. 3.8

2.326

3.120

2.972

2.09

2.826

2.794 
Table IV (conctinued)

\section{Vapor Presgure Data}

\begin{tabular}{|c|c|c|c|}
\hline $\begin{array}{c}\text { Sample } \\
\text { No. }\end{array}$ & $\begin{array}{l}\text { Vap r ressure } \\
\text { me. mercury }\end{array}$ & $\begin{array}{l}\text { Tempersture } \\
\text { deg. cent. }\end{array}$ & $\begin{array}{l}\text { Reciprocal } \\
\text { of } \mathrm{Abs} \text {. Temp } \\
\times 1000\end{array}$ \\
\hline 64. & $\begin{array}{r}249.5 \\
394.0 \\
565.0 \\
760.0 \\
96.5\end{array}$ & $\begin{array}{r}54.7 \\
4.6 \\
73.1 \\
30.4 \\
4.9\end{array}$ & $\begin{array}{l}3.052 \\
2.962 \\
2.90 \\
2.929 \\
2.794\end{array}$ \\
\hline 65. & $\begin{array}{l}153.0 \\
349.1 \\
549.6 \\
760.0 \\
902.1\end{array}$ & $\begin{array}{l}44.5 \\
61.5 \\
72.6 \\
0.2 \\
34.7\end{array}$ & $\begin{array}{l}3.150 \\
2.990 \\
2.994 \\
2.332 \\
2.796\end{array}$ \\
\hline 66. & $\begin{array}{l}151.0 \\
354.5 \\
566.5 \\
760.0 \\
905.5\end{array}$ & $\begin{array}{l}43.6 \\
61.1 \\
72.2 \\
79.4 \\
83.9\end{array}$ & $\begin{array}{l}3.159 \\
2.993 \\
2.97 \\
2.937 \\
2.002\end{array}$ \\
\hline
\end{tabular}




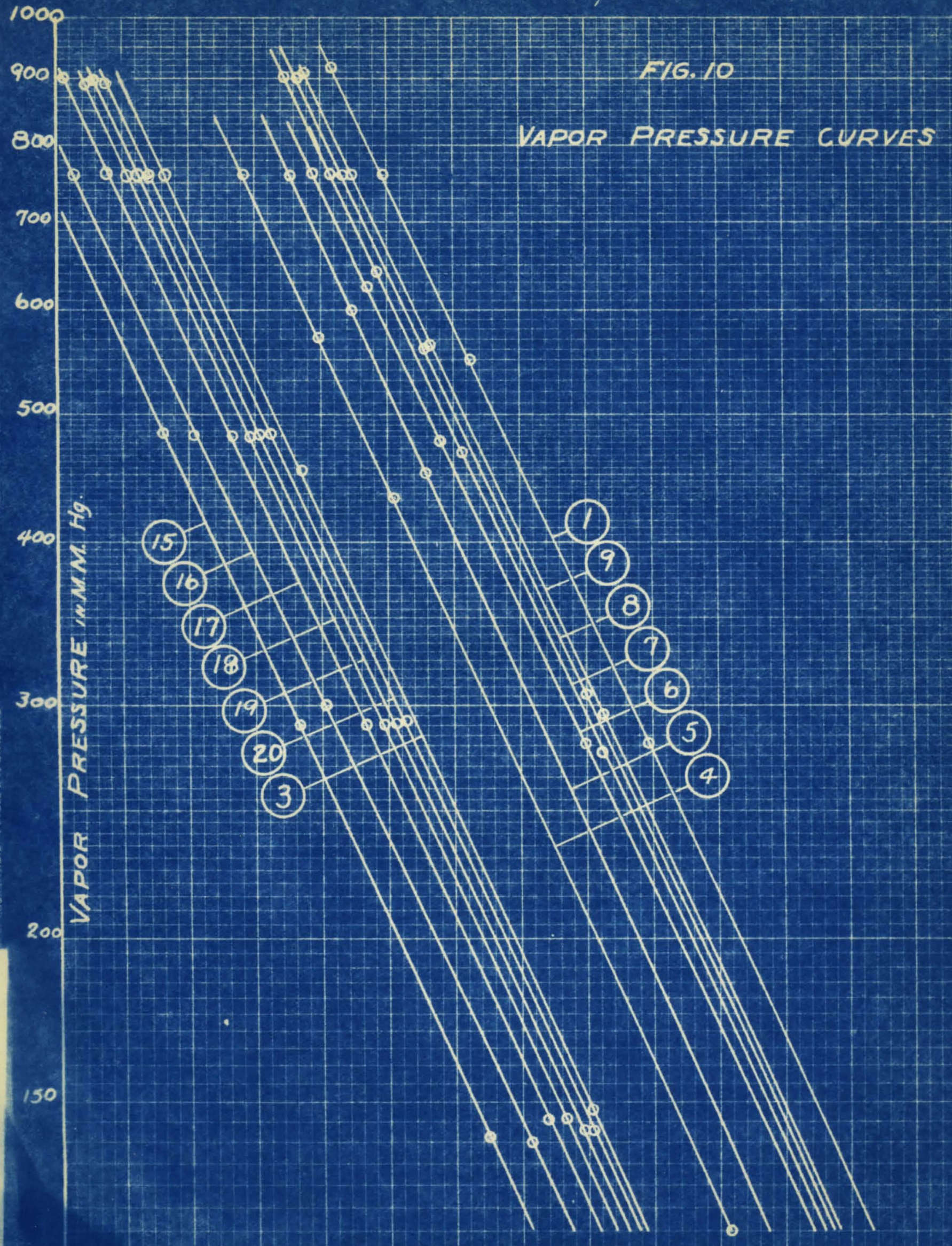




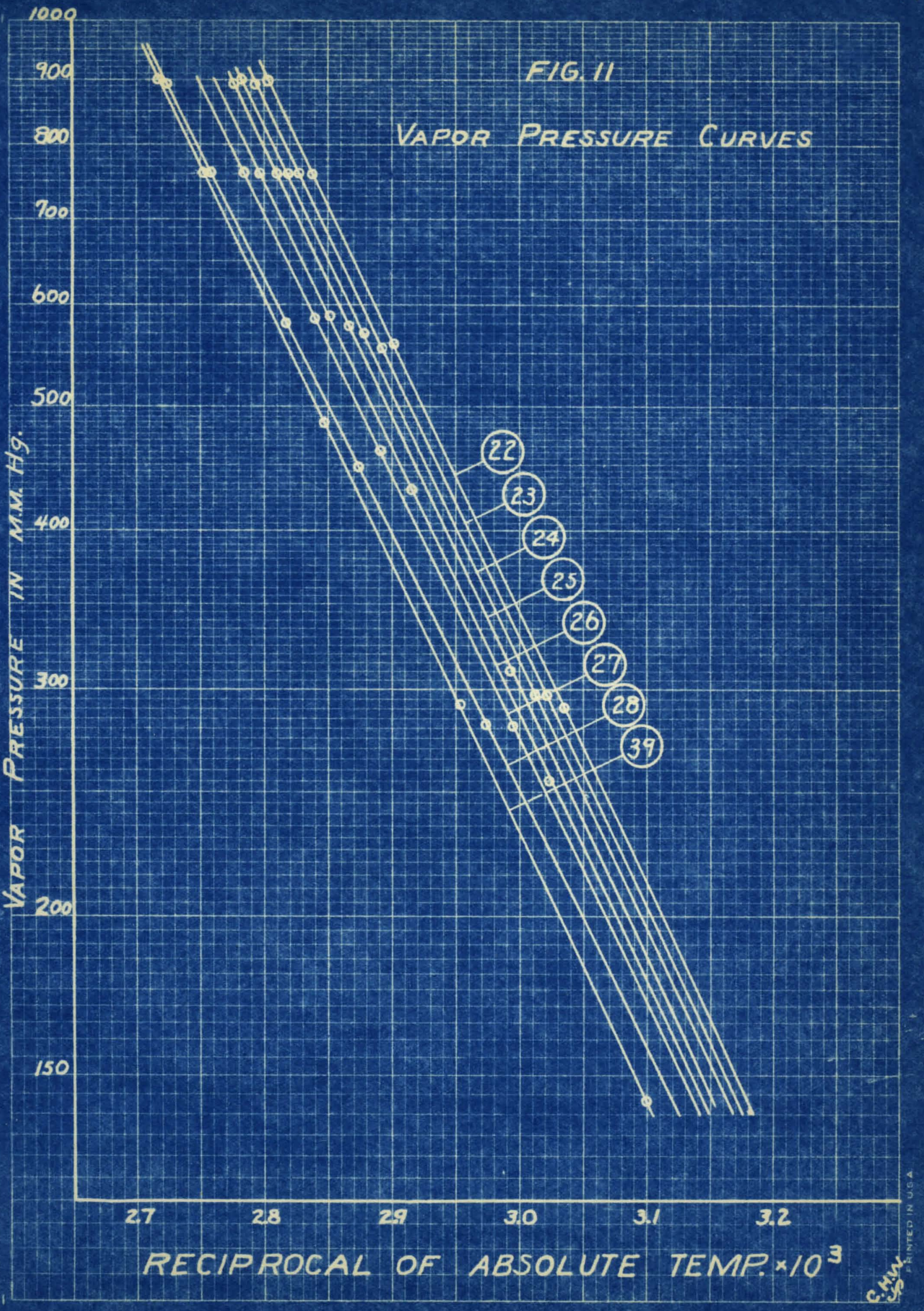




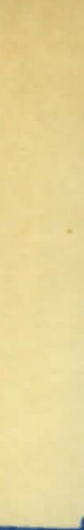

1000

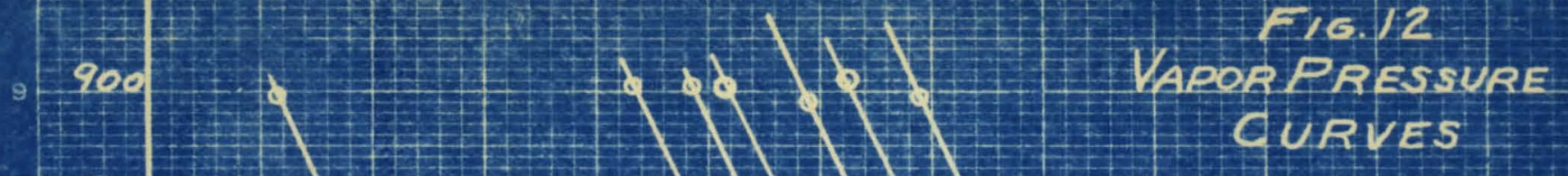

$88 a$

7700

60

के

5

$\frac{5}{5}$

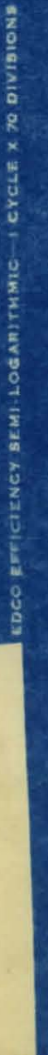

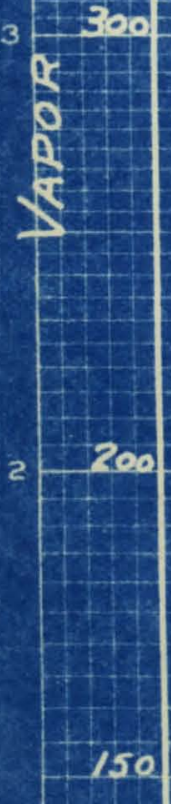

150 RECIPROCAL OF ABSOLUTE TEMR $\times 10^{3}$ 


\section{LATENT HEA:S}

The latent heate have been calculated for the entire system ua1ng the clauslus-Clapeyron equation as discussed in chapter II. These values are tabulated in Table III in Eram calories per mole.

Sample Calculations:

Equation uoed, I - R $\log \frac{\mathrm{D}}{\mathrm{p}_{1}} \div\left[\frac{1}{\mathrm{~T}_{1}}-\frac{1}{\mathrm{~T}_{2}}\right]$

Value obtolned from vapor preagure curve of sample number 42 are er follows-

$1 / T_{1}=.002968$

$1 / T_{2}-.002742$

$p_{1}=300 \mathrm{~mm}$. Hg.

$\mathrm{p}_{2}=900 \mathrm{~mm}$. $\mathrm{HE}$.

$1 / \mathrm{T}_{1}-1 / \mathrm{T}_{2}=.0002 ? 6$

$\log _{e} P_{2} / r_{1}-2.30310 g_{10} 3.000=2.303 \times 0.47712$

substititing in equation (s),

$L=\frac{2.30 \times 0.47712 \times 1.986}{.000226}-9.650$ calories per molo

It 15 noted that in arriving at equation (5) it wao assumed that $L$ was a constant, and this is not true. we know thet the latent heat of I1culds varles wh the presare at which vaporlzationtake place. This variation in latent heat is proportional to the change in slope of the vapor presgure Iines ( 10 p vs. $1 / T$ ). Since the vapor preasure data are used in this invetigation to calculate the latent heats, some error is encountered: however 1 t 18 emall. 
It 1s understood that the latent heate calculated here do not represent the value at a definite temperature and pressure but over a definite rance. This 18 the ranee of temperature and pressure aelected to aubstitute in equation (5), which in this investigation was betreen 300 and $900 \mathrm{~mm}$. mercury absolute.

There data are useful in the etudy of heat exchange In dietiliation, that $1 \mathrm{e}$, in calculating ateam coneumption, quantity of condenser water, etc. 


\section{VAPOR-LIQUID RQUILIERIUI: DATA}

Vapor-11quid equilibrium data for the ternary system are shown graphically in Fig. 13. The composition of the ilquid phase is represented by the poo1tion of the small circle. That 1s, the percent of water that any eample conteins is proportional to the distance of the point reprecenting that sample from the alde of the triangle oppoite the vertex labled water. Then to find the composition of any ample proceed as followe: From the point representing the composition of the eample, aram perpendiculars to each of the three nides of the triangle. The percent by welght of any component $1 \mathrm{~s}$ equal to the ratio of the correppo ding perpend1cular to the alti ude of the triangle. Thus, satule No. 6 contolne arproximately $39 \%$ glycerine, $21 \%$ ethanol, and 40 water.

The vapor phase if represented by a small dot. Each onall circle has a correspondine dot bearting the sane numbers. Thus, a rmall circle and a dot with the rame number represent equilibrium compositions of the 11quid and vapor phases renpectively.

From F1E. 13 1t can be seen that the 11qu1d compoe1t1ons vary over a wide ranee, whlle the vapor phase in equ1librlum w1th the 11quid containe no glycerine. 
The abrence of glycerine in the vapor phase is to be expected, because of the 10 vapor prearure of elycerIne below 100 deg. cent. ag shown in $\mathrm{FlE}$. 1 . It we found In this investigation that regardieg of the composition of the 11quid, the vapor phase contalned no elycerine except where the l1ạuld cample contalned above 60 per cont glycerine, and then only a trace $w a$ in the $v$ pr.

Table show the refrective index and density of the vapor and liguld camples, from phlch F15. 13 was prepared wh the ald of F1E. 4.

Curve 2 in F1g. 14 showe equ121brium compos1tions of the binary systen ethano?-water from the data of Carey and Lew1o (ZI). The graph is plotted weight percent ethanol in 11 u1d phane vereus welght percent ethanol in the vanor phase.

Curve 1 In Fig. 141 a plotted uging the same coordinates, but the data we taken from a ternary eystem Instad of a binary eysten ar in the cace of curve a. It can be ceen that curve I lies a ove curve throughout. Now consider two mivturee, No. 1 and No. 2, both conteinine zo\% ethanol, but No. 1 is a ternary oystem containing etranol, lycerine, a nd water vile No. 2 is a blnsy syotem of ethanol and weter. From F1E. 14 it can be een that eample No. I w11 contain more ethanol In vapor phase than No. 2. No. I has 5 ethanol in 
vapor phase and No. 2 has only $70 \%$ ethanol in vapor. It must, be borne in mind that curve 1 does not represent all posalble conditions, but is an average of the data contained. As the glycerine composition of the ternary bystem decreases, curve 1 aproachee curve 2. This is to be expected, since, when the glycerlne percertage is zero, the system w111 be a binary system (curve 2). Table VI, containing the data for curve I F1E. 14, obtalned from F1E. 13.

It har cen concluded that the three componentr, ethanol, Elycerine, and water in a mixture can be separated as follows:

1. By Fractionation, obtaining almost pure ethanol, and

2. By distiling the residue from 1 in a vacuum. The latter will remove all the water before the glycerine dist111s. 
TABLE $V$

Propertice of Vapor and Liqu1d Ehases

\begin{tabular}{|c|c|c|c|c|c|}
\hline Eample No. & $\begin{array}{l}\text { Liquid } \\
\text { Rerract1ve } \\
\text { Index }\end{array}$ & Density & $\begin{array}{l}\text { Boling } \\
\text { polnt } \\
\text { degrees } \\
\text { cent. }\end{array}$ & $\begin{array}{r}\mathrm{Var} \\
\text { Rerractiv } \\
\text { ind }\end{array}$ & Density \\
\hline 1. & 1.3904 & 0.9990 & 90.0 & 1.362 & 0.3270 \\
\hline 2. & 1.3549 & 1.0107 & 91.1 & 1.3614 & 0.3993 \\
\hline 3. & 1.3730 & 1.0450 & 37.2 & 1.3620 & 0.663 \\
\hline 4. & 1.3366 & 1.0042 & 99.5 & 1.3560 & 0.9 .70 \\
\hline 5. & 1.269 & 1.0707 & 100.0 & 1.3335 & 0.9990 \\
\hline 6. & 1.3949 & 1.0490 & 70.8 & 1.3621 & 0.141 \\
\hline 7. & 1.4103 & 1.0079 & 79.0 & 1.3613 & 0.3053 \\
\hline 3. & 1.4300 & 1.0380 & 73.2 & 1.3616 & 0.3032 \\
\hline 9. & 1.3995 & 1.1005 & 37.4 & 1.3622 & 0.753 \\
\hline 10. & 1.3912 & 1.1116 & 99.4 & 1.3420 & 0.9750 \\
\hline 11. & 1.3591 & 1.0500 & 99.6 & 1.3350 & 0.9922 \\
\hline 12. & 1.342 & 1.020 & 99.9 & 1.2340 & 0.9957 \\
\hline 12. & $1.369 ?$ & 0.9975 & 2.9 & 1.3630 & 0.530 \\
\hline
\end{tabular}


TABLEV (cont.)

Properties of varor and Miguld Phase

\begin{tabular}{|c|c|c|c|c|c|}
\hline Sample to. & $\begin{array}{l}\text { Liquid } \\
\text { Refract1ve } \\
\text { Index }\end{array}$ & Density & $\begin{array}{l}\text { poling } \\
\text { polnt } \\
\text { deg. con }\end{array}$ & $\begin{array}{r}\mathrm{Vap} \\
\text { Refract } 1 \mathrm{v} \\
\text { at. in }\end{array}$ & Density \\
\hline 14. & 1.3722 & 0.9495 & 1.0 & 1.3630 & 0.3445 \\
\hline 15. & 1.3700 & 0.990 & 79.6 & 1.3623 & 0.3285 \\
\hline 16. & 1.3377 & 0.9520 & 79.3 & 1.3632 & 0.9290 \\
\hline 17. & 1.3750 & 0.0640 & 7.3 & 1.3630 & 0.133 \\
\hline 1 . & 1.4240 & 1.1500 & $37 \cdot 3$ & 1.3630 & 0.3770 \\
\hline 19. & 1.4171 & 1.060 & 79.5 & 1.3640 & 0.303 \\
\hline 20. & $1 . \geq 620$ & 0.9736 & 33.3 & 1.3637 & 0.3565 \\
\hline 21. & 1.3427 & 0.9910 & 91.4 & 1.3610 & 0.9060 \\
\hline 22. & 1.3740 & 1.0230 & 4.7 & 1.3636 & 0.7593 \\
\hline 23. & 1.441 & 1.1790 & 22.7 & 1.3640 & 0.3500 \\
\hline 24. & 1.362 & 0.3324 & 7.3 & 2.3629 & 0.096 \\
\hline 25. & 1.3342 & 0.913 & 7.6 & 1.3632 & 0.914 \\
\hline
\end{tabular}


F/G.13

\section{VAPOR LIQUID EQUILIBRIUM \\ COMPOSITION DATA \\ O LIQUID PHASE \\ - vapor phase}

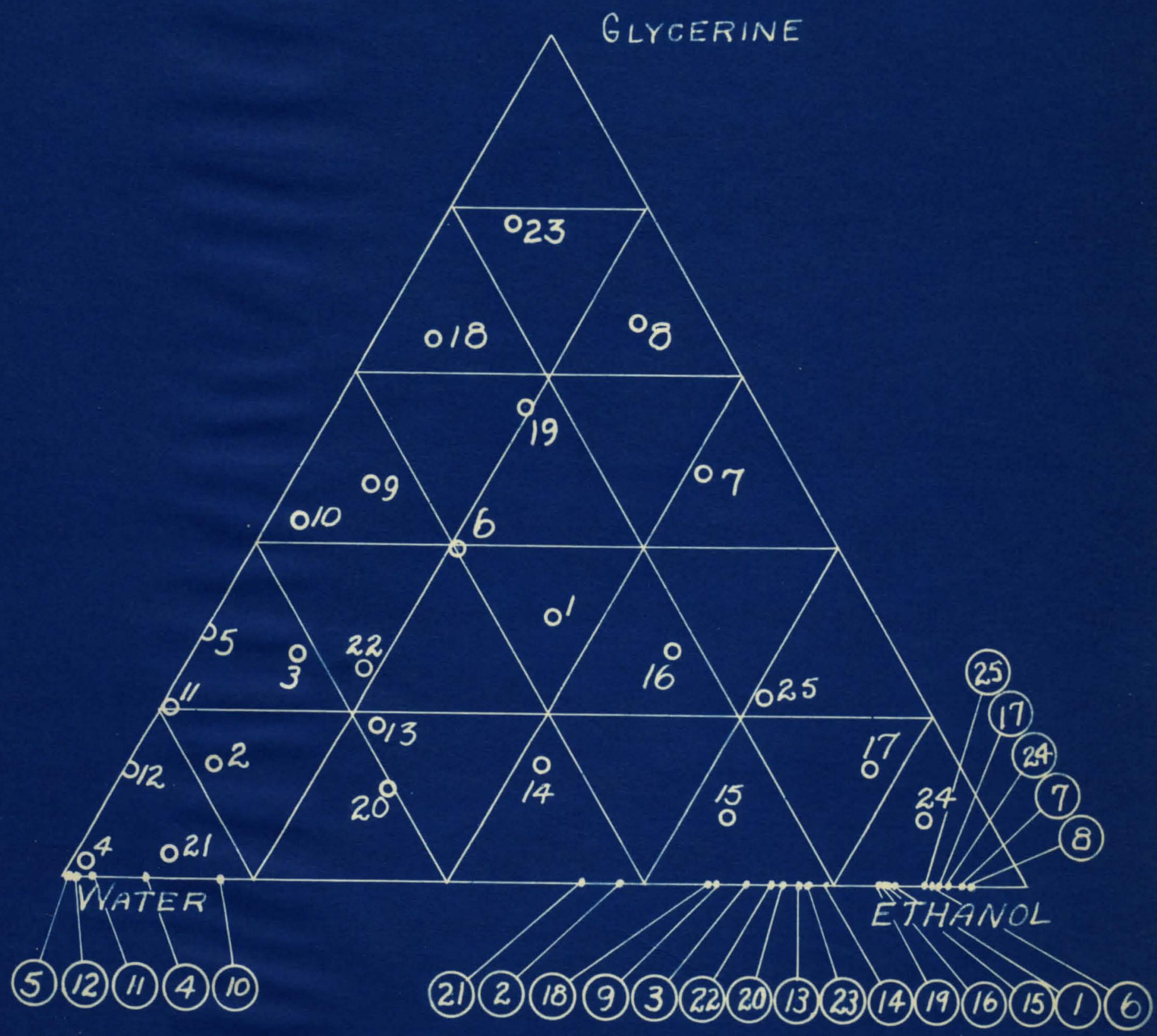




\section{TABLE VI}

Vapor-Iiquid Composition

\section{Sample \\ No}

1

2

3

4

5.

6

7

8

9

10

11

12

13
ETHSNOL CONTENT

Wt. Det.

LIQUTD

$\mathrm{VPO}$

35.1

36.0

8.8

58.0

11.0

70.3

1.5

9.0

0.5

0.3

21.0

90.0

42.0

93.0

$25 \cdot 5$

94.0

3.1

6.0

$\because .5$

16.8

1.0

3.4

0.6

1.6

23.3

76.5 


\section{TABLE IV (cont'd)}

\section{VAFOR-LI ID COMOSITION}

Sample

14.

15.

16.

17.

18.

19.

20 .

21.

22.

23.

24.

25.
ETHANOL CONTENT

wt. Pet.

$\begin{array}{rr}\text { LIQUID } & \text { VAPOR } \\ 42.5 & 79.0 \\ 64.7 & 35.5 \\ 49.0 & 5.0 \\ 76.2 & 90.5 \\ 6.0 & 36.8 \\ 19.0 & 34.5 \\ 23.0 & 74.5 \\ 9.0 & 34.0 \\ 12.0 & 73.5 \\ 7.2 & 77.5 \\ 4.9 & 91.5 \\ 61.4 & 39.0\end{array}$


Fig. 14

VAPOR-LIOUID EQUILIBRIUAM CURVES FOR ETHANOL

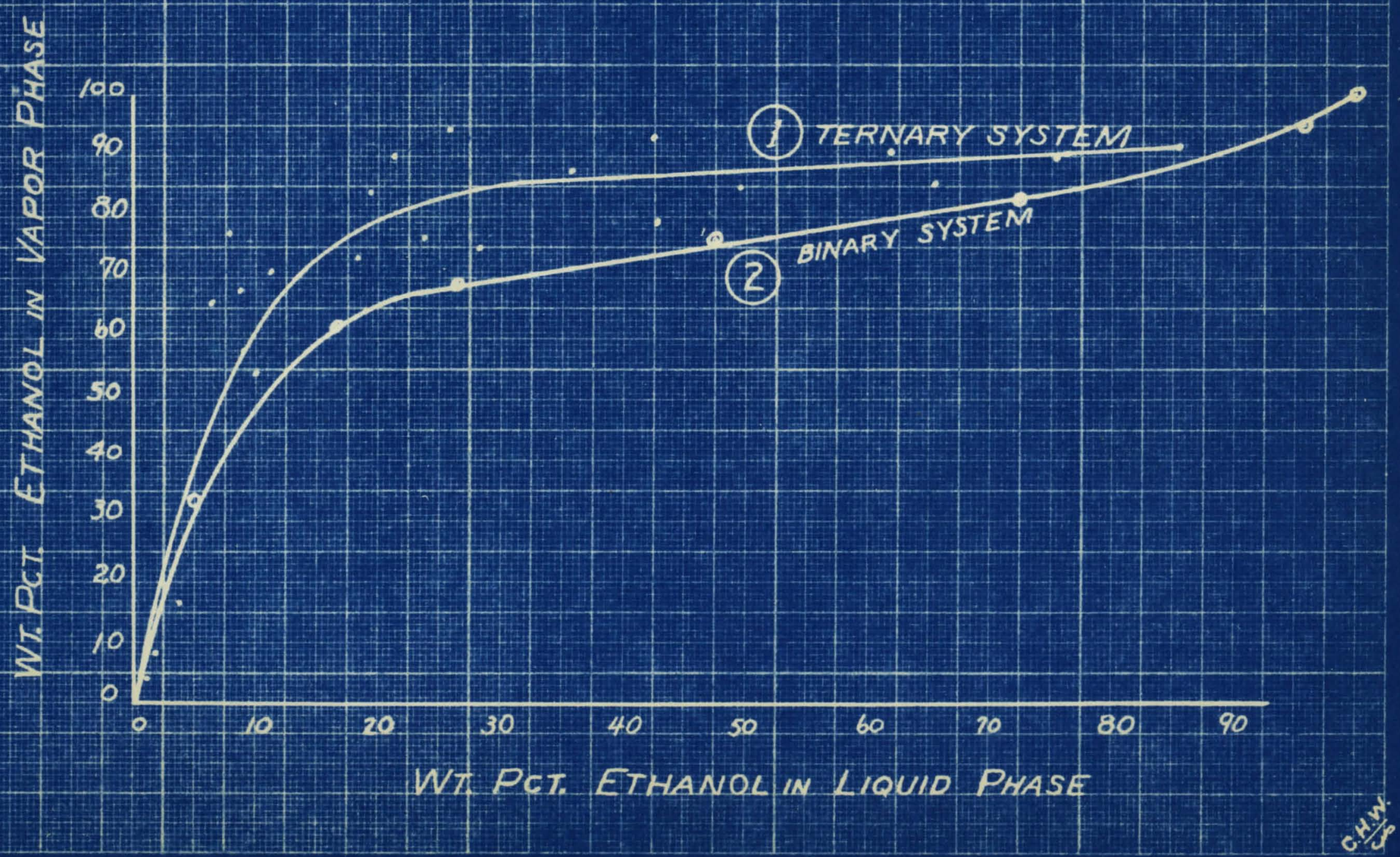


FREEZING FOINTS

The primary object of this investigation was to determine those propertiee that are airectly related to alotillation-namely, snecific heats, bollIne pointe, vapor pregsurer, latent heats, and vaporIlquid equilibrium data: but, elnce the three mater1alo are 1mportent in blnary mixturee as commerclal antifreeze olutions, frezing polnte were determined.

Acetone, coojed with eolld cerbon dioxide, wae ueed as the freezing mixture. A toluene themoneter, graduated in one degre sudivisions, was used to determine the temperatures. Camples containing leos than fifty per cent water did not glve definite freezing points. Theee samples usually roculted in the formation of celatinous macses, and gave no definite freosing point. Table VII containe the freezIne nointe that were obtained. Fif. 15 lo a plot of these values. The values for the binary eyctem Gycerine-weter arree wh those of Lane (32). 
The constant per cent water lines reach a minimum when ethanol and lycerine contente are equal. This means that for an antifrceze with a certain freezing point, a greater water content may be used if the rebulting per cent is made up of equal parts of ethanol and glycerlne instead of being made up of elther one ceparately.

The triangular diagram (F1C. 16) ohowa 211 the posfible compostione having the bame freesing point. 
TABLE VII

Freezing points

\begin{tabular}{|c|c|c|c|}
\hline $\begin{array}{c}\text { Sample } \\
\text { No. }\end{array}$ & $\begin{array}{l}\text { Freezine Point } \\
\text { degrees cent. }\end{array}$ & Sarnple No. & $\begin{array}{l}\text { Freezing Polnt } \\
\text { degrees cent. }\end{array}$ \\
\hline 1. & -115.0 & 34. & -44.0 \\
\hline 3. & -0.0 & 35. & -30.0 \\
\hline 4. & $-2 . ?$ & 36. & -19.0 \\
\hline 5. & -9.0 & 37. & -12.0 \\
\hline 6 & -19.0 & 30 & -7.0 \\
\hline 7. & -27.0 & 42. & -50.0 \\
\hline . & -34.6 & 43. & -34.0 \\
\hline 9. & -42.5 & 44. & -23.0 \\
\hline 10. & -53.0 & 45. & -15.0 \\
\hline 16. & -30.5 & 49. & -53.0 \\
\hline 17 . & -26.5 & 50. & -37.5 \\
\hline 13. & -16.5 & 51. & -27.0 \\
\hline 19. & -9.6 & 55. & -52.0 \\
\hline 20. & -5.7 & 56. & -33.0 \\
\hline 21. & -2.5 & 60. & -50.0 \\
\hline
\end{tabular}




\section{Fio.15}

freezing point diagram

$-10.4$

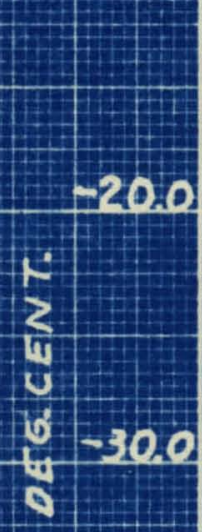

$\frac{k}{d}-40.0$

$\frac{0}{\mathrm{~N}}-50.0$

iv

0.0

-

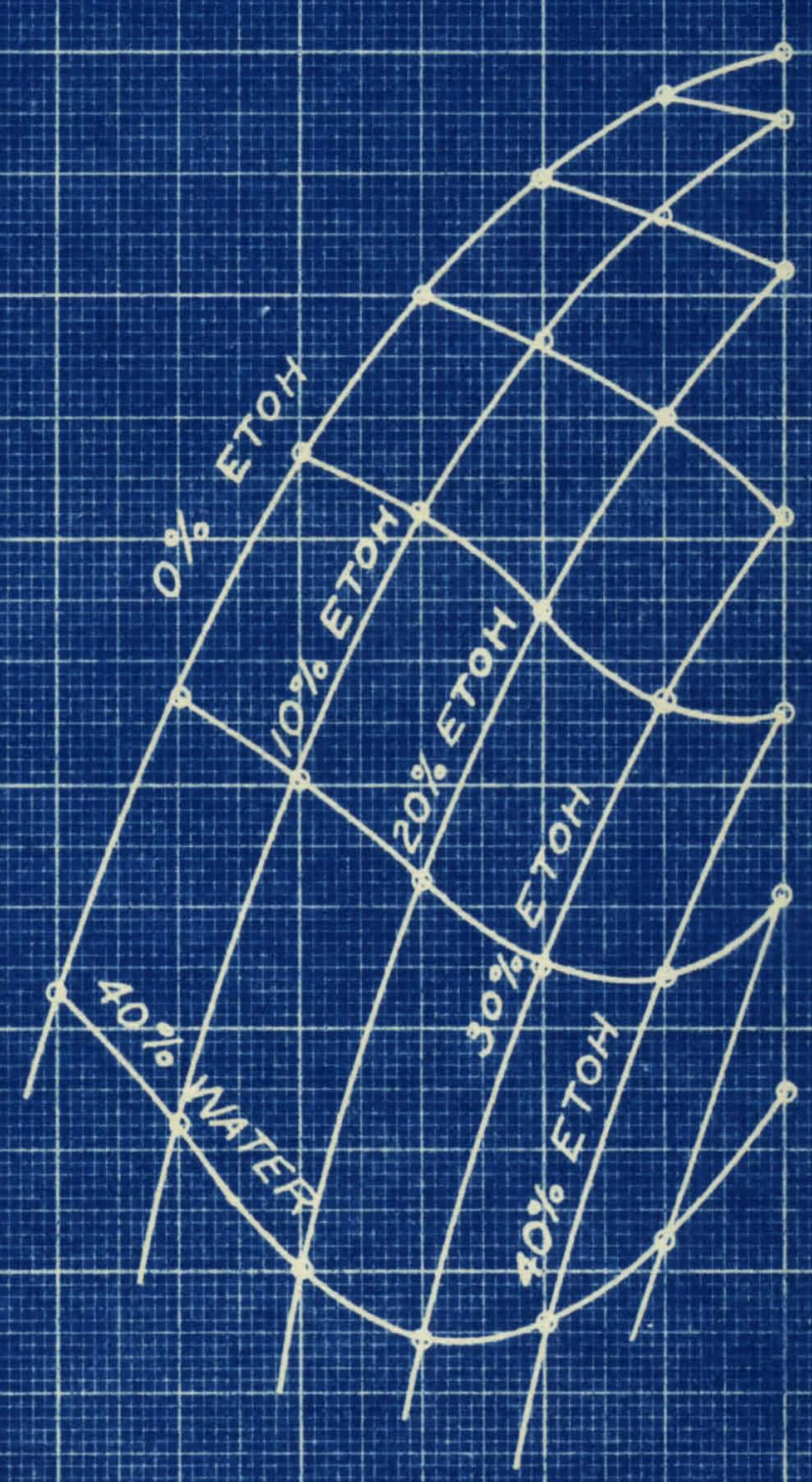

$-6.0 .0$

$\begin{array}{rlllll}100 & 60 & 60 & 40 & 20 & 0\end{array}$

NEIGHT BERCENT GLYGERINE 
F/G. 16

\section{FREEZING POINT DIAGRAM}

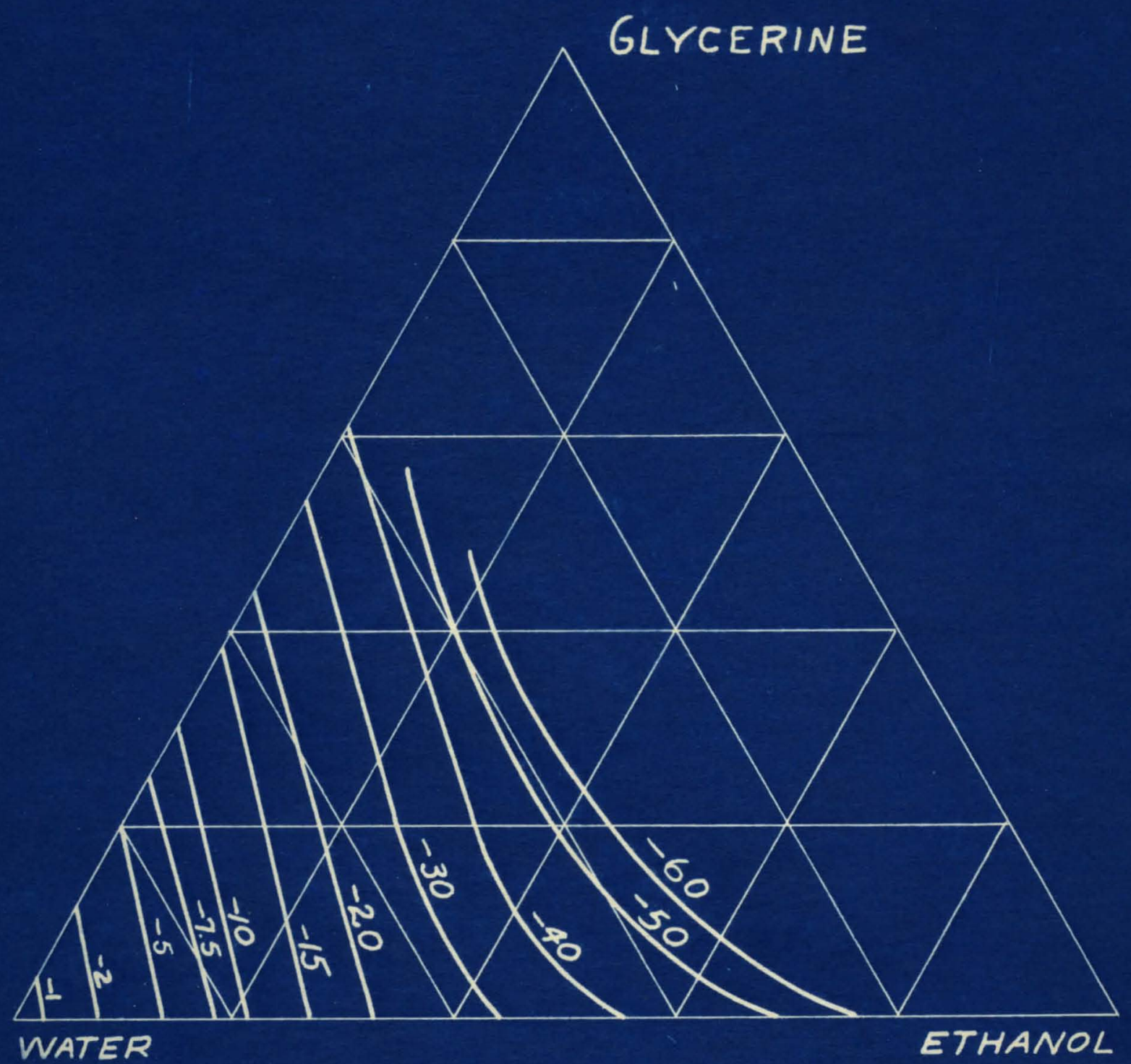




\section{CHAPTER V}

\section{CONCLUSIONS}




\section{CONCLUSIONS}

Speolflee hente, bolling polnte, vapor pressures, latent heats, and vapor-11quid equilibrium date have been reported in this alseertetion. These properties and the propertiea reported in a previous investiestion (1) complete the preliminary work on this eystern in the study of dietiliation of ternary mixturee. Freezing polnts heve been added because ethanol and glycerine in aqueous nolutions are of interest as commerclal ant1-freeze mixtures.

The properties reported in the previous invest1gation (1) were precented before the "1a-west regional metine of the Amerlcan Chemlcal Soclety, November 1 , 1935 in Loulsv11'e, Kentucky, and were accepted by the Journal of hyslcal chemistry for publication and w111 appear in May, 1936 Edition. 
CHAFTER VI

BIBLIOGRA THY 


\section{BIBLIOGRAPHY}

1. Watkins, C.H.: Thes1e, 1935; inlvero1ty of Loulovilie,

2. Nelman, R. : Thes1s, 1934, University of Louloville

3. Daniele and Getman: Elemente of Theo. Chem. 128 (1931) (J.H.).

4. Iyer and Uscher: J. Chem. Soc. London, 127, 341 (1925).

5. E. Abbe: Carlo Repertarium der Phy $1 \mathrm{k}, 15$, 643 (1379).

6. Richards and Gucker: J. Am. Chem. Soc. 47, 1976 (1925).

7. D. F. Othmer: Ind. Ene. Chem., 20,743 (1923).

3. Brunjes and Furnas: Ind. Eng. Chem., 27, 396 (1925).

9. Ernet, Litkenhous and spanyer: J. Phys. Chem., $36,342(1932)$.

10. Cottrell: J. Am. Chem. Soc., 41, 721 (1919).

11. Bosart and snoddy: Ind. Enf. Chem., 20, 1377 $(1028)$.

12. Chappins: Travaux et memolrs du bureau international des nolde et meacuree, 13: D 40 (1907).

13. Bircumchaw: J. Chem. Toc., London, 121, 307 (1922).

14. Durcker: Ze1thochrlft furrphystkaliache Chemie, Stolchionetrie and Verwand-schaftslehre, 52, 641 (1905). 


\section{BIBLIOGR FIIY}

cont'd.

15. Andrews: J. Am. Chem. soc., 30,353 (1905).

16. Richarde and Carver: J. Am. Chem. Soc. 43, 327 (1921).

17. Jayner: J. Chem Soc., London, 121, 1511 (1922).

13. The Isen, cheel, and D1eoselhorst: W1or. Abhand. Phyo. Tech. Relchaandtalt, 2,6 (1900).

19. Dunstan and Thale: J. Chem. Soc., London 95, 1556 (1905).

20. Sheely: Ind. Ene. Chem., 24, 1061 (1932).

21. Quincke: A. Thyo1k, 44,774 (191).

22. Osborne, Yckelvy and Bearce: Bureau of Stde., Bulletin No. 9,227 (1913).

23. Winkler: Belchte der Deutcchen chemischen Gesellachaft, 29, 3612 (1905).

24. Sheely: Ind. Eng. Chem., 24, 1063 (1932).

25. Vag1e: Phyolcal eview, 16, 331 (1003).

26. Bosart and noddy: Ind. Wne. Chem. 19,506 (1927).

27. Doroghevk11 and Pollanski1: ze1techrift fur

rhysike.1 the chemle, Stochlometrie and V erwandtgchaftelehre, 73, 192 (1910).

23. Mayer-Bugetron: zeltochrift der deutechen $\mathrm{OL}$ und Fet1-Industrie, 44, 417 (1924).

29. Noyes and terfel: J. Am Chem. Soc., 23, 463 (1901). 
BIBLIOGRATHY

$$
\text { cont'a. }
$$

30. Morgan and Scarlet: J. Am. Chem. Soc., 39, 2275 (1917).

31. Carey and Lew1s: Ind. Eng. Chem., 24, 332 (1932).

32. Lane: Ind. Eng. Chem. 17, 925 (1925). 